

IZADP No. 2564

Worker Characteristics, J ob Characteristics, and Opportunities for Phased Retirement

Robert Hutchens

J anuary 2007 


\title{
Worker Characteristics, Job Characteristics, and Opportunities for Phased Retirement
}

\author{
Robert Hutchens \\ Cornell University \\ and IZA
}

\author{
Discussion Paper No. 2564 \\ January 2007
}

IZA
P.O. Box 7240
53072 Bonn
Germany

\author{
Phone: +49-228-3894-0 \\ Fax: +49-228-3894-180 \\ E-mail: iza@iza.org
}

\begin{abstract}
Any opinions expressed here are those of the author(s) and not those of the institute. Research disseminated by IZA may include views on policy, but the institute itself takes no institutional policy positions.
\end{abstract}

The Institute for the Study of Labor (IZA) in Bonn is a local and virtual international research center and a place of communication between science, politics and business. IZA is an independent nonprofit company supported by Deutsche Post World Net. The center is associated with the University of Bonn and offers a stimulating research environment through its research networks, research support, and visitors and doctoral programs. IZA engages in (i) original and internationally competitive research in all fields of labor economics, (ii) development of policy concepts, and (iii) dissemination of research results and concepts to the interested public.

IZA Discussion Papers often represent preliminary work and are circulated to encourage discussion. Citation of such a paper should account for its provisional character. A revised version may be available directly from the author. 
IZA Discussion Paper No. 2564

January 2007

\section{ABSTRACT}

\section{Worker Characteristics, Job Characteristics, and Opportunities for Phased Retirement}

This paper uses a telephone survey of 950 employers to examine employer-side restrictions on phased retirement. Not only did the survey collect information on establishment level policies, it also asked questions about a specific worker's opportunity for phased retirement. The paper uses these data to first establish that employers are selective when offering opportunities for phased retirement. It then examines what worker and job characteristics are particularly important in the selection process.

JEL Classification: J26, J23, J14

Keywords: retirement, older workers, part-time employment, pensions

Corresponding author:

Robert Hutchens

School of Industrial and Labor Relations

Cornell University

342 Ives East

Ithaca, NY 14853

USA

E-mail: RMH2@cornell.edu 


\section{Worker Characteristics, Job Characteristics, and Opportunities for Phased Retirement}

Phased retirement is often seen as a way to encourage continued labor force participation by the baby boom generation. ${ }^{1}$ The basic idea of phased (or gradual) retirement is that a worker remains with his or her employer while gradually reducing work hours and effort. Some argue that this could not only provide a more satisfying path to full retirement, but could also preserve specific human capital and thereby enhance productivity. In light of such potential benefits, it is rather surprising that phased retirement is so rare. Studies from the 1980s find that for a cohort of retirees, less than ten percent took phased retirement; most retirements took the form of moving from full-time work to fulltime withdrawal from the labor force. ${ }^{2}$ More recent data provides no evidence of a substantive increase in such numbers. ${ }^{3}$

Since older employees often express an interest in phased retirement, ${ }^{4}$ one explanation for its scarcity focuses on employers. Perhaps employers simply do not permit workers to take phased retirement. That explanation has now been questioned by at least two recent surveys of employers; William M. Mercer, Inc. (2001) and Hutchens (2003) find that while formal phased retirement policies are rare, most employers can and do negotiate hours reductions by older workers on an informal basis.

But perhaps such findings do not go far enough. When employers say that they would permit some form of informal phased retirement, perhaps what they are really saying is that phased retirement is an option for a select group of high performing hard-to-replace older employees. By this argument, since only a few workers fall into this select group, most older employees do not, in fact, have an opportunity for phased retirement. This paper uses unique data on older white-collar workers to investigate whether, in fact, employers are selective in granting opportunities for phased retirement. 
The data come from a representative sample of 950 establishments. Thanks to a grant from the Sloan Foundation, the University of Massachusetts Center for Survey Research conducted telephone interviews with employers on the topic of phased retirement by white collar workers. Hutchens and Grace-Martin (2006) use these data to analyze why establishments differ in their policies toward phased retirement. Although this paper uses the same survey, it exploits a different and unique set of questions on an individual worker. One of the paper's contributions to the literature lies in describing a survey methodology for obtaining information on an individual worker from an employer. Another contribution lies in the application of multiple imputation to these data. Finally, the paper analyzes the data with multivariate methods, thereby indicating what types of workers have especially good (or bad) opportunities for phased retirement.

The next section discusses the rationale for the survey and describes the survey questions that focus on phase retirement. Section II then sketches a theoretical framework, Section III presents the data, Section IV discusses missing data and multiple imputation, and Section V analyzes the data using ordered probit models. The results indicate that employers are, in fact, selective in offering opportunities for phased retirement, and that employee characteristics -- including age and performance -- influence the likelihood of selection.

\section{Selective Opportunities for Phased Retirement}

Much of the empirical literature on phased retirement is based on individual level data. The basic goal in this literature is to explain reduced hours (and in some cases earnings) by older workers in the context of a labor supply model, e.g., Gustman and Steinmeier (1983, 1984, 1985), Reimers and Honig (1989), Ruhm (1990), and Quinn, Burkhauser, and Myers (1990). As such, the key explanatory variables are the individual's wage, financial wealth (perhaps including pension and social security wealth) as well as demographic characteristics. Such research leads naturally to a question about the role that employers play in the phased retirement decision. If employers restrict phased retirement opportunities, with some workers having better opportunities than others, then 
models estimated in individual level data may not reflect labor supply behavior. While that is not a new idea (see, for example, Gustman and Steinmeier, 1983), it highlights how little we know about opportunities for phased retirement. There is simply no information about whether or why employers are selective in permitting workers to take phased retirement. A survey of employers is a good way to learn more about that.

As such, a telephone survey of 950 establishments was undertaken between June 2001 and November 2002. In order to obtain detailed information in a relatively brief interview, the survey focused on white collar workers. ${ }^{5}$ The survey research firm first contacted a sample establishment and asked for the person who is best able to answer questions about flexible work schedules and employee benefits, for example a human resource manager or benefits manager. Although details of the survey are provided in Section III, it is useful at the outset to introduce two survey questions (labeled Q1 and Q2) that were used to assess opportunities for phased retirement.

First, after asking a series of question about the characteristics of the establishment and its human resource and pension policies, the interviewer posed the following question:

Q1. Think of a secure full-time white-collar employee who is age 55 or over. One day that person comes to you and says that at some point in the next few years he/she may want to shift to a part-time work schedule at this establishment. Could this person's request to shift to part-time employment be worked out in a way that would be acceptable to your establishment?

If the response was "yes" or "in some cases," then additional questions were asked about the nature of this hours reduction and the conditions under which it could occur.

While this question about a generic white-collar employee is useful in that it provides information on the employer's policy regarding phased retirement, it does not permit an assessment of whether phased retirement is used selectively for workers in specific types of jobs or for particularly productive workers. That issue was pursued by asking questions about an actual older worker. The interview proceeded as follows:

So far, we have been talking about general policies at your establishment. I'd now like to ask about more specific situations. In order to answer these questions, it is easiest to talk about an actual person who does an actual job in your establishment. 
To begin with, I would like you to give me the first names of three [men/women] age 55 or over who are full-time white-collar employees in your establishment. If it would make you more comfortable, you can give me fictitious names, but please think of specific employees. You should know the work of these employees reasonably well. For example, they may be people you supervise. If possible, it would be best if these three employees have different job titles.

This question was randomized on gender. Roughly half of the employers were asked for three men, while the other half were asked for three women. ${ }^{6}$

Given the three first names, one name was chosen at random and the subsequent questions focused on characteristics of the selected worker, the nature of that worker's job, and the worker's opportunity for phased retirement. ${ }^{7}$ Of course, if the employer had indicated that phased retirement was not permitted at the establishment, we obtained the other information but did not ask about the selected worker's opportunity for phased retirement. If, however, phased retirement was possible, we asked the following:

Q2. Earlier you indicated that it might be possible for a full-time employee age 55 or over to shift to a part-time work schedule. ${ }^{8}$ On a scale from 1 to 5 , where 1 means not at all likely and 5 means very likely, how likely is it that [fill person's first name] could shift into a part-time position?

This question provides a means to assess whether some employees have better opportunities for phased retirement than others.

Note that the question focuses on employer perceptions rather than the occurrence of actual phased retirements. That is in line with the goal of this paper, which is to examine opportunities for phased retirement. The occurrence of an actual phased retirement not only requires that an employer provide the opportunity, but also that an employee decide to seize that opportunity. By implication, data collected from employers is deficient for studying whether phased retirements actually occur; by their nature such data do not include information on the determinants of an employee's decision to seize the opportunity. ${ }^{9}$

Table 1 presents summary statistics on Q1 and Q2 for the 950 surveyed establishments. According to the second column, 639 (67\%) of the 950 establishments indicated that that phased 
retirement would be feasible for a generic white-collar worker, and another $142(15 \%)$ of the establishments said that phased retirement was possible in some cases. In most of these establishments, the employer has in mind an informal arrangement that is negotiated with an individual worker and that occurs before official retirement. Formal phased retirement plans are rare, especially in small organizations.

As indicated in the third column of Table 1, information was obtained on a selected worker in most of these establishments, and employer responses to Q2 are reported in columns labeled "1" through " 5 " on the right side of the table. It is interesting to note how dispersed the answers are. Employers who said "yes" to phased retirement for a generic white-collar worker (Q1) would often say "yes" to phased retirement for the selected worker. Thus, there are real workers who have a real opportunity for phased retirement. But that was not always the case. Some selected workers got a clear "no." The policy is obviously not the same for all; the results in Table 1 are thoroughly consistent with the hypothesis that employers are selective in granting opportunities for phased retirement.

There remains, of course, the question of why employers would be selective. Are they granting opportunities for phased retirement to a select type of workers, or are certain jobs particularly appropriate for phased retirement? A theoretical framework is useful for examining such issues.

\section{Theoretical Framework}

Consider a firm that employs two workers over two periods. Since this section examines why employers may be selective in offering phased retirement, assume that the firm does not rule out phased retirement a priori. Alternatively stated, assume the firm answers Q1 above with "Yes" or "In Some Cases."

Let the firm's production function be of the form $f\left(h_{1}, h_{2}, \theta\right)=\sum_{j=1,2} f\left(h_{j}, \theta_{j}\right)$ where $h_{j}$ is 
the number of hours worked by employee $j, \theta_{j}$ is vector of technological parameters, and $\partial \mathrm{f}\left(h_{j}, \theta_{j}\right) / \partial h_{j}$ $>0$ and $\partial^{2} \mathrm{f}\left(h_{j}, \theta_{j}\right) / \partial h_{j}^{2}<0$ for $h_{j}>0, \mathrm{j}=1,2$. For example,

$$
\mathrm{f}\left(h_{j}, \theta_{j}\right)=\theta_{0 j}+h_{j}-\theta_{1 j}\left(h_{j}-H\right)^{2},
$$

where $H$ represents full-time hours, and $\theta_{1 \mathrm{j}}>0, \mathrm{j}=1,2$.

The firm maximizes profits over two periods. It provides specific training to employee $\mathrm{j}$ in the first period (bearing a fixed training $\operatorname{cost} \mathrm{T}_{\mathrm{j}}$ ), and produces output in the second. For simplicity, assume the firm receives a price of " 1 " for each unit of output, that the discount rate is zero, that second period employees either work full-time $(H)$ or part-time $(1 / 2 H)$, and that first period trainees always work full-time $(H)$. Although the subsequent analysis is equally applicable to daily, monthly, or annual hours, for heuristic purposes it may be easiest to think of " $H$ " as 40 hours per week.

The firm pays employee $\mathrm{j}$ a first period wage of $W_{j}^{1}(H)$, and a second period wage of $W_{j}^{2}(H)$ if full-time or $W_{j}^{2}(1 / 2 H)$ if part-time, $\mathrm{j}=1,2$. These wages are choice variables for the firm; it sets them subject to the constraint that employees are at least as well off as they would be in the external labor market. Let the market determined relationship between hours and earnings be $\mathrm{A}(h)$ where $\partial \mathrm{A}(h) / \partial h>0$, and assume that the two employees confront the same $\mathrm{A}(h)$. Thus, both have an alternative full-time and part-time wage of $\mathrm{A}(H)$ and $\mathrm{A}(1 / 2 H)$. From the perspective of other (outside) employers, the two employees are identical.

Figure 1 illustrates $\mathrm{f}\left(h_{1}, \theta_{1}\right), \mathrm{f}\left(h_{2}, \theta_{2}\right)$ and $\mathrm{A}(h)$. Note that at full-time hours both workers produce output greater than the alternative wage, i.e., $\mathrm{f}\left(h_{\mathrm{j}}, \theta_{\mathrm{j}}\right)>\mathrm{A}(H), \mathrm{j}=1,2$. This gap could be due to either the specific training received in period 1 , or to worker characteristics that are observed by the firm, but not by the market. For example, while outsiders view them as identical, the current employer may observe that employee 2 is careful and industrious while employee 1 is careless and indolent.

In summary, the firm maximizes profit by selecting the optimal second period hours and optimal first and second period wages for each worker subject to the constraint that the workers are 
no worse off than they would be in alternative jobs. ${ }^{10}$ This style of model has been analyzed before in the literature. ${ }^{11}$ For present purposes it suffices to note that if the technology and market relationship between hours and the alternative wage is like that depicted in Figure 1, then at the beginning of period 1 the firm and its employees enter into an agreement whereby both employees work full-time $(H)$ in the second period. In exchange the firm promises to pay them second and first period wages $W_{j}^{2}(H) \geq A(H)$ and $W_{j}^{1}(H)=2 A(H)-W_{j}^{2}(H), \mathrm{j}=1,2$.

Now, in the context of this model, why are employers selective in offering phased retirement? Suppose that at the beginning of the second period -- despite having previously agreed to work fulltime -- employee 1 requests phased retirement, i.e., the employee asks to be shifted to part-time work and threatens to quit if not permitted to do so. This request could be due to a change in tastes, health status, or wealth. A quit could obviously result in lost profit and thereby be costly to this firm. Under what circumstances will the firm accommodate the worker's request? It is straightforward to show that a necessary condition for the firm to permit this reduction in hours is,

$\mathrm{f}\left(1 / 2 H, \theta_{1}\right)-\mathrm{A}(1 / 2 H) \geq 0$.

Intuitively, what matters is the revenue generated by the part-time job, $\mathrm{f}\left(1 \frac{1}{2} H, \theta_{1}\right)$, and the alternative part-time wage, $\mathrm{A}(1 / 2 H)$. If condition (2) does not hold (i.e., $\left.\mathrm{f}\left(1 \frac{1}{2} H, \theta_{1}\right)<\mathrm{A}(1 / 2 H)\right)$, then a "deal" is not possible. Were the firm to provide a part-time job paying $\mathrm{A}(1 / 2 H)$, then the firm loses money. Alternatively, were the firm to pay a wage equal to the revenue generated by the part-time job $\left(\mathrm{f}\left(1 / 2 H, \theta_{1}\right)\right)$, then the employee would quit for a better paying job elsewhere.

The firm in Figure 1 would refuse the request for phased retirement by employee 1, since condition (2) does not hold for this employee. The condition does, however, hold for employee 2; had employee 2 made the same request, the firm may well have granted it. Thus, for the firm in the Figure 1, some employees have an opportunity for phased retirement while others do not.

What employee and job characteristics will influence whether an employee has such an opportunity? It is useful to think about this in terms of the curvature of $\mathrm{f}\left(h_{\mathrm{j}}, \theta_{\mathrm{j}}\right)$ and the gap between 
the full-time product and the full-time alternative wage $\left(\mathrm{f}\left(H, \theta_{\mathrm{j}}\right)-\mathrm{A}(H)\right)$. Decreases in the curvature and increases in the gap will increase the left hand side of condition (2). For example, for the technology in (1) we have,

$$
\mathrm{f}\left(1 / 2 H, \theta_{\mathrm{j}}\right)-\mathrm{A}(1 / 2 H)=\mathrm{C}-\theta_{1 j} \frac{H^{2}}{4}+\left[\mathrm{f}\left(H, \theta_{\mathrm{j}}\right)-\mathrm{A}(H)\right]
$$

where $\mathrm{C}$ is a constant of the form, $\mathrm{C}=\mathrm{A}(H)-\mathrm{A}(1 / 2 H)-1 / 2 H$. It follows that employee and job characteristics that either decrease the curvature of $\mathrm{f}\left(h_{\mathrm{j}}, \theta_{\mathrm{j}}\right)$ or increase the gap between $\mathrm{f}\left(H, \theta_{\mathrm{j}}\right)$ and $\mathrm{A}(H)$ are likely to increase opportunities for phased retirement. For example, individual characteristics that are not easily observed by outside employers (e.g., creativity or a willingness to make an extra effort to get things done) are likely to increase the gap between $\mathrm{f}\left(H, \theta_{\mathrm{j}}\right)$ and $\mathrm{A}(H)$, and thereby be associated with phased retirement, ceteris paribus; that should not be the case for more easily observed characteristics (like years of schooling) that affect both $\mathrm{f}\left(H, \theta_{\mathrm{j}}\right)$ and $\mathrm{A}(H)$. Similarly, job characteristics that increase the curvature of $f($ ) (e.g., the job involves the work of a team of employees in the same place at the same time) are less likely to be associated with phased retirement. These ideas are developed below and implemented in the subsequent empirical work.

\section{The Data}

The data consist of a representative sample of 950 establishments. Details of the data collection methods and the sample universe can be found in Hutchens (2003) as well as Hutchens and Grace-Martin (2006). For present purposes it suffices to note that the sample was restricted to establishments not engaged in either agriculture or mining with twenty or more employees and at least two white-collar employees who are age 55 or more. ${ }^{12}$ The latter restriction not only insures that questions about phased retirement are relevant to the establishment's current situation, but also that employers can answer questions about a specific older worker (Q2).

The overall response rate was $61 \%$. Most of the nonresponse occurred when screening establishments for eligibility (e.g., at least two white collar employees age 55+), and before 
respondents knew the purpose of the survey. Interviews were completed in $89 \%$ of the establishments that were successfully screened. This is on a par with other establishment level telephone surveys. ${ }^{13}$

\section{Characteristics of the Selected Worker}

In terms of the model in Section II, worker characteristics should play a role in phased retirement to the extent that they influence the gap between $\mathrm{f}(H, \theta)$ and $\mathrm{A}(H) .{ }^{14}$ In particular, individual productive characteristics that are easily observed by outside employers should have little bearing on phased retirement, while more difficult to observe characteristics should be important.

To implement this empirically, the survey asked several questions about the worker's more easily observed demographic characteristics (age, education, gender, health status), as well as less easily observed measures of performance. For example, the employer was asked, "on a scale from 0 to 10 , where 0 means the worst possible employee and 10 means the best possible employee, how would you rate (name's) job performance.” Questions were also asked about how closely the employee must be supervised, the employee's creativity in solving problems, and willingness to put forth extra effort to get the job done. The appendix presents exact wordings.

Characteristics of the job

In terms of the model in Section II, job characteristics can indicate the extent to which a job is technologically compatible with part-time work. Even within an establishment, one would expect the curvature of $\mathrm{f}\left(h_{\mathrm{j}}, \theta_{\mathrm{j}}\right)$ to differ across jobs. There should be little curvature in a job like processing insurance claims; the job can be handled by one full-time clerk or by two part-timers. While the two part-timers may have considerable firm-specific experience and skill, the job is repetitive and does not require extensive coordination between the clerks. In contrast, the job of manager may have substantial curvature in $\mathrm{f}\left(h_{\mathrm{j}}, \theta_{\mathrm{j}}\right)$. One full-time manager is likely to be much more productive than two part-timers. Suppose a managerial job is split in half: Person A is manager in the morning and Person $\mathrm{B}$ is manager in the afternoon. Other things equal, a manager working full-day would be more 
productive than the two part-timers because the full-day manager does not have to spend time and energy communicating what happened in the previous half day. In line with the argument in section II, an establishment may permit phased retirement by clerks, while prohibiting managers from doing the same. ${ }^{15}$

Three types of proxies are used to capture a job's technological compatibility with part-time work. First, the survey included questions on the selected worker's occupation (manager, professional, clerical, and sales). Second, the employer was asked whether there are regular part-time workers in the selected worker's job category. Since the selected worker is a full-time employee, the presence of part-timers in the same job category suggests a technology that is compatible with parttime work. Third, the literature indicates that part-time work is particularly feasible when a job involves working alone and tasks that are discrete in the sense that they have a clear beginning and end, and are relatively self-contained (see Nollen, Eddy and Martin, 1977, 1978). More generally, jobs involving coordination and communication among members of a team tend to be incompatible with part-time work (Hurd, 1996). Thus, the employer was asked whether the selected worker's job involves working alone, discrete tasks, and frequent or close communication with other members of a group. Again, the specific questions are in the appendix.

Job characteristics may also affect phased retirement by being associated with the gap between $\mathrm{f}\left(H, \theta_{\mathrm{j}}\right)$ and $\mathrm{A}(H)$. For example, one would expect increased specific training to increase the size of this gap. To address this, the survey included questions about the selected worker's job tenure as well as whether employer sponsored training occurs in the selected worker's job. Since specific training is unobservable, none of these variables are ideal. However, they should at least be correlated with specific training and thereby phased retirement.

Skill depreciation may also influence the gap between $\mathrm{f}(H, \theta)$ and $\mathrm{A}(H)$. In some jobs young workers may on average out-perform workers over (say) age 55. If aging is associated with a decrease in $\mathrm{f}(H, \theta)$ relative to $\mathrm{A}(H)$, then the gap would fall. To implement this in the empirical work, the 
survey asked whether the selected worker's job requires several years of experience to do well, and whether older workers are, on average, more or less productive than younger workers.

Another job characteristic that could conceivably influence phased retirement is whether the job is difficult to fill. Although it does not strictly fit into the above two period model, the employer's assessment of the worker's threat to quit will depend crucially on whether the job is difficult to fill. If a replacement can be easily found, then the threat of a quit - and the associated loss in profit implicit in the gap between $\mathrm{f}(H, \theta)$ and $\mathrm{A}(H)$-- will be of little concern. To implement this empirically, questions were asked about whether there are contingent or temporary workers in the selected worker's job title, whether the employer has experienced increased difficulty in filling the selected worker's job over the past five years, and how many months it would take to fill the job if the selected worker quits.

Other Individual Level Variables

Yet another factor that may influence phased retirement is the worker's pension coverage. Of particular importance are defined benefit pensions. Unlike defined contribution plans, under a defined benefit plan an older worker who shifts from full-time to part-time may suffer a substantial loss in future pension benefits. Moreover, unlike a defined contribution plan, workers with a defined benefit plan are often not able to draw pension benefits without changing employers. ${ }^{16}$

Hutchens and Grace-Martin (2006) find essentially no evidence that pensions influence establishment-level policy toward phased retirement. There remains, however, the question of whether pensions influence individual-level policy. In the complex world of employee benefits, different employees at the same firm can have different pensions. This may be due to the employee's past choices (e.g., choice between the firm's earlier defined benefit plan and its new 401(k)), or the employer's decision to change coverage for specific types of workers, (e.g., managers hired after January 1, 1995 are covered by plan B). If phased retirement is, in fact, negotiated at the individual level, then whether or not a specific individual is covered by a defined benefit or defined contribution 
plan could matter. For purposes of the subsequent empirical work, extensive data were collected on the selected worker's pension coverage. Once again, the appendix provides details.

Any analysis of pensions and phased retirement should include information on coverage by a collective bargaining agreement. Pension coverage is correlated with unionization, and unions may affect phased retirement in ways that go beyond pensions. In particular, since phased retirements are often informal "deals" negotiated between an employee and employer, unions may seek to limit such arrangements, preferring that phased retirement be part of a comprehensive agreement covering the full membership of the bargaining unit. Moreover, unions tend to prefer that jobs be full-time rather than part-time. ${ }^{17}$ As such, the subsequent empirical work includes a measure of whether the individual worker is covered by a collective bargaining agreement.

\section{Establishment Characteristics}

Establishment characteristics may also play a role in a selected worker's opportunities for phased retirement. For example, holding personal and job characteristics fixed, a clerk in a manufacturing establishment may have less opportunity for phased retirement than a clerk in a law office. It is useful to think about this is in terms of a marginal and conditional probability. There is a marginal probability that -- as revealed by Q1 -- the establishment permits phased retirement. Write this probability as $\operatorname{Pr}\left(\mathrm{Y}_{1 \mathrm{i}}=1\right)$, where $\mathrm{Y}_{1 \mathrm{i}}=1$ if individual $\mathrm{i}$ works in an establishment where the answer to Q1 is "yes" or "in some cases", and $\mathrm{Y}_{1 \mathrm{i}}=0$ otherwise. There is also a conditional probability that -- as revealed by Q2 -- the selected worker has an opportunity for phased retirement. Since the answers to Q2 are on a scale from 1 to 5 , write this conditional probability as $\operatorname{Pr}\left(\mathrm{Y}_{2 \mathrm{i}}=\mathrm{k} / \mathrm{Y}_{1 \mathrm{i}}\right.$ $=1$ ), where $\mathrm{Y}_{2 \mathrm{i}}$ equals $\mathrm{k}$ with $\mathrm{k}=1,2, \ldots, 5$, depending on the answer to $\mathrm{Q} 2$ for individual $\mathrm{i}$. Then the

probability that $\mathrm{Y}_{2 \mathrm{i}}=\mathrm{k}, \mathrm{k}=1,2, \ldots, 5$ can be written as the product of a conditional probability and a marginal probability, i.e.,

$$
\operatorname{Pr}\left(\mathrm{Y}_{2 \mathrm{i}}=\mathrm{k}\right) \equiv \operatorname{Pr}\left(\mathrm{Y}_{2 \mathrm{i}}=\mathrm{k} \mid \mathrm{Y}_{1 \mathrm{i}}=1\right) \operatorname{Pr}\left(\mathrm{Y}_{1 \mathrm{i}}=1\right)
$$


Letting $\mathrm{X}_{1 \mathrm{i}}$ be a vector of personal and job characteristics for individual $\mathrm{i}$, and $\mathrm{X}_{2 \mathrm{i}}$ be a vector of characteristics for i's establishment, this can also be written,

$$
\operatorname{Pr}\left(\mathrm{Y}_{2 \mathrm{i}}=\mathrm{k} \mid \mathrm{X}_{1 \mathrm{i}}, \mathrm{X}_{2 \mathrm{i}}\right) \equiv \operatorname{Pr}\left(\mathrm{Y}_{2 \mathrm{i}}=\mathrm{k} \mid \mathrm{Y}_{1 \mathrm{i}}=1, \mathrm{X}_{1 \mathrm{i}}, \mathrm{X}_{2 \mathrm{i}}\right) \operatorname{Pr}\left(\mathrm{Y}_{1 \mathrm{i}}=1 \mid \mathrm{X}_{1 \mathrm{i}}, \mathrm{X}_{2 \mathrm{i}}\right)
$$

The present paper estimates a model of the conditional probability, $\operatorname{Pr}\left(\mathrm{Y}_{2 \mathrm{i}}=\mathrm{k} \mid \mathrm{Y}_{1 \mathrm{i}}=1, \mathrm{X}_{1 \mathrm{i}}\right.$, $\left.\mathrm{X}_{2 \mathrm{i}}\right)$. For this purpose, the vector of establishment characteristics $\left(\mathrm{X}_{2 \mathrm{i}}\right)$ comes from Hutchens and

Grace-Martin (2006), which essentially estimates a model of the marginal probability. ${ }^{18}$ Included in $\mathrm{X}_{2 \mathrm{i}}$ are variables indicating industry, region, establishment size, establishment demographics (e.g., percent female), establishment level pension policies and other relevant establishment-wide policies like job sharing and a flexible starting time.

\section{Summary Statistics}

Table 2 presents summary statistics on the selected workers and their jobs.

The first four columns permit comparisons between selected workers in establishments that permit phased retirement (column 1 and 2) and do not permit phased retirement (column 3 and 4). The numbers in columns 1 and 3 are the average value of the selected worker's characteristics in such establishments, while those in columns 2 and 4 are the corresponding standard deviations for the averages. The right hand side columns $5-8$ then permit comparisons between selected workers who are in an establishment that permits phased retirement and have good (column 5 and 6) or not so good (columns 7 and 8) opportunities for phased retirement.

Consider the first four columns. Looking at the demographic characteristics, the selected workers in establishments that permit phased retirement (columns 1 and 2) are quite similar to those in establishments that do not permit phased retirement (columns 3 and 4). For example, the selected worker's average age in establishments that permit phased retirement is 58.65 while the corresponding number in establishments that do not permit phased retirement is 58.25 . Note also that the standard error in columns 2 and 4 is the standard error of the mean. The standard deviation for the age of the selected worker in the sample is, of course, much larger. In fact, the standard deviation for 
age is 3.95 , and ages range from 55 to 85 . On average, the selected workers have some post-high school education and are in good health. As noted above, by design roughly half of the selected workers are men and the other half women.

Part B of the table presents information on the performance of the selected workers as assessed by the survey respondent. Questions were asked about overall performance as well as specific dimensions of performance. It would be surprising if establishments with and without phased retirement exhibited significant differences in these measures. Take, for example, the question on whether the selected worker easily learns new procedures and technologies when they are introduced in the workplace. There is no reason to think that such a worker is more or less likely to be selected in establishments that permit phased retirement. It is reassuring that the results in Table 2 support that. The means in column 1 and 3 of part B are statistically indistinguishable.

Part $\mathrm{C}$ of the table addresses occupation while Part D presents data on characteristics of the selected worker's job that indicate compatibility with part-time work. For these Part D job characteristics there is good reason to expect differences between columns 1 and 3. An example is variable (18), which indicates that there are regular part-time workers in the selected worker's job title. The answer to this question was much more likely to be "yes" in establishments that permitted phased retirement. Of course there is a good explanation for this: if there are part-time jobs in the selected worker's job title, then there are part-time jobs in the establishment. It is easier for an employer to accommodate phased retirement when there are part-time jobs in the establishment.

In the remaining parts of Table 2 there are few significant differences between columns 1 and 3. The principal exceptions occur for pensions and union status (part $\mathrm{H}$ ). Selected workers in establishments that permit phased retirement (column 1) are more likely to be covered by a defined contribution pension and less likely to be covered by a collective bargaining agreement. Once again, this is in part because the individual characteristic is correlated with establishment characteristics (e.g., a defined contribution plan for the establishment) that influence the establishment level policy regarding phased retirement. ${ }^{19}$ 
Turning to columns $5-8$ in Table 2 , here the focus is on selected workers in establishments that permit phased retirement. Columns 5 - 8 compare selected workers who have good (columns 5 and 6) and not so good (columns 7 and 8) opportunities for phased retirement. The table indicates several important differences.

1) There are demographic differences. Those with good opportunities tend to be older.

2) There are performance differences. Those with good opportunities score higher on most dimensions of performance except salary. ${ }^{20}$

3) There are occupational differences. Those with good opportunities tend to not be managers.

4) There are pension differences. Those with good opportunities are more likely to have a defined contribution pension and less likely to have a defined benefit pension.

5) There are job differences. Selected workers with good opportunities for phased retirement were more likely to be in a job title that includes regular part-time workers. Consistent with columns 1 and 3, they are also less likely to be in a job covered by a union contract.

The results in Tables 1 and 2 imply that employers are selective in choosing candidates for phased retirement, with older high performers at the front of the queue. There remains the issue of whether these results hold up in multivariate models.

\section{Missing Data and Multiple Imputation}

Like most surveys, this survey of 950 establishments suffers from missing data; not only were some questions answered with "not applicable" or "don't know," but, as indicated in Table 1, data on a selected individual (Q2) were provided by $811(85 \%)$ of the 950 establishments. Of course, that raises concerns about biased parameter estimates in multivariate models. The best way to address this

problem is for it not to happen, i.e., collect data so that each respondent provides complete answers to each question. In actual surveys, however, despite every effort, such perfection is not possible. 
As such, one contribution of this paper lies in estimating multivariate models after applying multiple imputation. Multiple imputation was pioneered by Rubin (1987); Brownstone and Valletta (2001) provide a particularly informative introduction to the methods and the literature. The basic idea is to first estimate a parametric model that can impute values for the missing data, and thereby create K new data sets with no missing data. Multivariate models are then estimated in each of these $\mathrm{K}$ data sets, average values of each coefficient computed across data sets, and variation in those estimates used to obtain standard errors for the estimated coefficients.

Although applications to establishment level data are rare, multiple imputation is particularly well-suited to such data. In the present case the initial sample of establishments was drawn from a universe that included detailed information on each of the establishments. ${ }^{21}$ As such, for all 950 establishments there exist complete data on several variables (e.g., industry, location, employment, and sales growth), and this information can be combined with respondent provided information to impute data to all establishments. ${ }^{22}$ By implication, even if an establishment did not provide information on a selected worker, such information can be imputed.

Of course, since it rests on assumptions about the nature of the mechanism that generates the missing data, multiple imputation is not the same as having actual data. It should, however, be recognized that one can not impute missing data without making assumptions, and that due to the missing data, those assumptions can not be verified. The chief virtues of a multiple imputation methodology are that it is based on a statistical theory, it is straightforward to apply, and assumptions are explicit.

An alternative way to address missing data is through listwise deletion, whereby any observation with missing data is excluded from the analysis. Since listwise deletion does not use all of the non-missing data, it is inferior to multiple imputation. Moreover, listwise deletion can lead to biased parameters in situations where multiple imputation is unbiased. Application of listwise deletion in the subsequent multivariate work reduces the number of observations from 796 to 437 , but, as detailed below, yields results that are quite similar to those based on multiple imputation. 


\section{Multivariate Models}

This section uses multivariate models to examine the probability that an individual has a good opportunity to take phased retirement. Tables $3 \mathrm{a}$ and $3 \mathrm{~b}$ present estimates of the probability that, conditional on being in an establishment that permits phased retirement (thus, conditional on the answer to Q1 being "yes" or "in some cases"), the selected individual has a good opportunity for phased retirement. The models in 3a examine individual demographic and performance characteristics, while those in $3 \mathrm{~b}$ address job and pension characteristics. Since the dependent variable takes values 1 through 5, all models are estimated with ordered probit.

Demographic characteristics are introduced in the first model in Table 3a. A key conjecture was that worker characteristics that can be easily observed by outside employers will have little to do with phased retirement. That is borne out by the results on education and gender, but not by the result on age. There is clear evidence in this and subsequent models that opportunities for phased retirement increase with age. This is discussed further below.

The second and third models in Table 3a introduce the respondent's assessment of the selected worker's performance. The second model uses the overall assessment of job performance. As noted above, the respondent was asked to rate the selected worker on a scale from 0 to 10 where 0 is the worst possible employee and 10 is the best possible employee. The coefficient on this variable is positive and statistically significant at conventional levels. Thus, job performance influences an employee's opportunities for phased retirement. ${ }^{23}$

The third model essentially asks what aspects of job performance influence opportunities for phased retirement. Here we get the surprising result that what matters is not creativity or ability to learn, but rather being the kind of person who works without much supervision and makes extra effort to get the job done. There is logic to this result. From an employer's perspective, a full-time worker who requires constant supervision and still puts forth minimal effort is probably not worth keeping on as a part-timer. Either the worker remains full-time or leaves (perhaps fully retires). In economic 
parlance, the person may not put forth sufficient effort for the employer to recoup the fixed monitoring costs. ${ }^{24}$

Note that as expected, those worker characteristics that are most strongly related to phased retirement tend to be characteristics that are not easily observed by outside employers. The key exception here is the worker's age. Why would someone who is 65 years old have better opportunities for phased retirement than someone who is $\mathbf{5 5}$ years old, ceteris paribus? One possible answer is that an older worker can more credibly threaten to quit. He or she may be eligible for social security and perhaps a pension. If not permitted to take phased retirement, then a quit followed by full or partial retirement is a feasible option. Another possible answer is that as workers age, the retirement process acts as a selection mechanism that effectively retains the "high performers." The latter interpretation emphasizes the role that phased retirement may play in retention, i.e., in order to discourage retirement by particularly valuable workers, the employer offers them phased retirement. Consistent with this interpretation, note that when performance measures are introduced in the second and third models, the coefficient on age drops a bit. That suggests that job performance is, in fact, part of the reason for the positive relationship between age and opportunities for phased retirement. However, the fact that the age coefficient remains positive and statistically significant in both models indicates that there is more to the story than job performance. Even after controlling for performance, older workers have greater opportunities for phased retirement.

The fourth model in Table 3a includes the job characteristics from the fourth model of Table 3b, while the fifth model in Table $3 \mathrm{a}$ introduces establishment level variables. It is interesting how little effect these additional variables have on the coefficients for demographic and performance characteristics. $^{25}$

Turning to Table $3 \mathrm{~b}$, whereas Table $3 \mathrm{a}$ focuses on characteristics of the individual, $3 \mathrm{~b}$ focuses on characteristics of the job. The first model simply introduces occupation dummies. The results indicated that phased retirement is somewhat less feasible for managers and professionals than for 
clericals and sales people (the excluded category). The coefficients are not, however, statistically significant.

The second model in Table $3 \mathrm{~b}$ introduces the vector of job characteristics. Several of the coefficients are statistically significant with expected signs. For example, if there are regular parttimers in the selected worker's job, then phased retirement is more feasible. Note also the negative coefficient on "employer-sponsored training rarely or never occurs." Although the coefficient is statistically insignificant, the negative sign is consistent with the hypothesis that phased retirement is more likely in jobs that involve specific training. Moreover, the variable "job where young are more productive than old" has a negative and statistically significant sign. One interpretation would be that phased retirement is less likely when job skills depreciate rapidly with age. Finally, as indicated by the positive and statistically significant coefficient on "if SW left job, how many months would it take to fill?" there is evidence that phased retirement is more likely in jobs where it is difficult to find a replacement.

The third model in Table $3 \mathrm{~b}$ introduces pension dummies as well as a dummy variable indicating that the job is covered by a union contract. With regard to pensions, the results indicate that -- consistent with expectations -- workers covered by a defined benefit pension (or by both a DB and DC pension) tend to have less opportunity for phased retirement than those who are only covered by a DC pension. Note also the negative and statistically significant coefficient on the union variable. This result is in line with above noted claim that collective bargaining affects phased retirement opportunities in ways that go beyond pensions.

The fourth model introduces variables that measure the demographic and performance characteristics of the selected worker (i.e., the variables in Table 3a), and the fifth model introduces establishment level variables. The fourth and fifth models indicate that when these additional variables are included, some of the previously discussed coefficients on job characteristics become statistically insignificant. The implication is that characteristics of jobs tend to be correlated with both the characteristics of the workers in those jobs as well as establishment characteristics. It follows that 
-- at least for some variables -- it is not statistically feasible to distinguish the effects of job characteristics from person and establishment characteristics in these data. For example, while some of the skill and training variables are robust to the Model 4 inclusion of worker characteristics, the coefficient on "job where young are more productive than old" drops in magnitude and statistical significance. A cautious interpretation would be that due to the correlation between this variable and worker characteristics, there is no solid statistical basis for claiming a relationship between the variable and phased retirement opportunities. ${ }^{26}$

One can, however, go too far with such arguments. For example, the pension and union coefficients drop in magnitude and statistical significance when the establishment characteristics are added in model 5. This happens in large part because the establishment characteristics include variables indicating the types of pensions available in the establishment, and the percent of the establishment's white collar workers who are covered by a collective bargaining agreement. The results in model 5 indicate that we can not distinguish an individual level effect from these establishment level effects. That is, however, not really relevant. In a model where the dependent variable indicates an individual's opportunity for phased retirement, the appropriate measure of pensions and collective bargaining is at the individual level. While the Model 5 inclusion of establishment level variables affects the coefficients, it does not alter the conclusion that when an individual is covered by a defined benefit pension or a collective bargaining agreement, then that individual has reduced opportunities for phased retirement, ceteris paribus. ${ }^{27}$

Finally, since the results in Table 3 are based on multiple imputation, it is reasonable to ask whether the results are robust to listwise deletion, whereby an observation is omitted if it suffers from missing data. Appendix B Tables 4a and 4b present the relevant results. (Referee: if length is an issue, these tables could be omitted or available from the author.) Almost all of the above noted statistically significant results are robust to listwise deletion. An exception is the coefficient on defined benefit pensions in Appendix Table 4b, model 4; the coefficient retains its negative sign but is no longer statistically significant at conventional levels. Thus, while one may choose to be cautious about the 
defined benefit pension results, the key results in this paper - the results on worker performance and opportunities for phased retirement - are obtained with and without multiple imputation.

\section{Conclusion}

This paper examines the extent to which employers are selective in providing opportunities

for phased retirement. Previous work establishes that employers are often open to an informal arrangement whereby an older white collar worker can move from full-employment to part-time. The question addressed in this paper is whether employers are chiefly open to phased retirement for select employees.

The evidence presented here strongly indicates that some older white collar workers are, indeed, particularly likely to have a good opportunity for phased retirement, and that personal characteristics matter. This is true in simple cross-tabulations as well as in multivariate models that hold job and establishment characteristics constant. In particular, as age increases so do opportunities for phased retirement. Moreover, employers are more likely to permit phased retirement by people who are high performers in the sense that they require little supervision and make an extra effort to get the job done.

The evidence is less clear about the importance of job characteristics. Some job characteristics do, in fact, matter. The models yield the very plausible result that if there are regular part-time workers in the selected worker's job title, then there are greater opportunities for phased retirement. This result is robust over a broad range of models. There is also evidence that workers in jobs that involve employer training are more likely to have opportunities for phased retirement. However, for several other job characteristics examined here, conclusions are simply not possible. Job characteristics are correlated with establishment characteristics. When characteristics of the establishment are entered in the model, coefficients on job characteristics often become statistically insignificant. 
It is interesting to think about these results in terms of using household or individual level survey data to estimate labor supply models of an individual's phased retirement decision. The evidence strongly indicates that an individual's opportunities for phased retirement depend not only on the kinds of variables obtained through household or individual level surveys (such as wages, demographic characteristics, or occupation), but also on characteristics of the individual's employer (such as existence of part-time jobs within the individual's job title), as well as aspects of the individual's work performance (such as whether the individual requires little supervision). A labor supply model of the phased retirement decision would ideally incorporate such determinants of opportunity.

It is also interesting to think about these results in terms of similarities with Japan. Japanese employers sometimes provide work opportunities for some of the employees who reach the organization's mandatory retirement age (Rebick, 1995). These post-career jobs involve reduced hours with the current employer or an affiliate of the current employer. Since Japanese employers are often selective about who has an opportunity for such jobs, with high performing employees having greater opportunities, this practice has been viewed as a motivational device. The present paper finds a similar phenomenon in the U.S; phased retirement is offered selectively, with high performing employees having greater opportunities. Are there situations where U.S. employers use phased retirement as a motivational device?

Finally, it is interesting to think about these results in terms of formal versus informal phased retirement plans. We know that formal plans are rare. Perhaps that is because employers want to be selective about who has an opportunity for phased retirement. It may be easier to be selective when there is no document that could be interpreted as granting workers a "right" to phased retirement. 


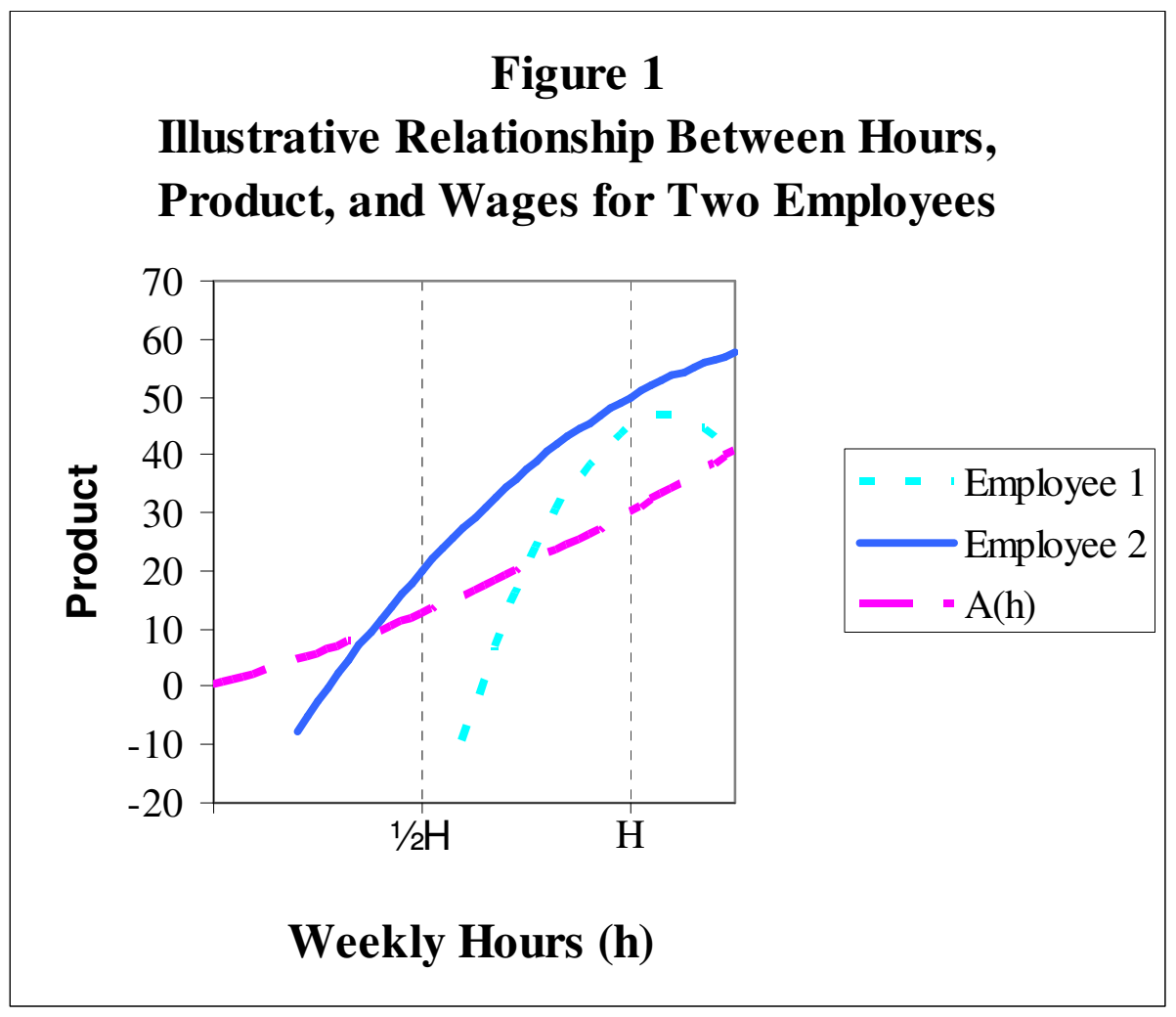


Table 1

Responses to the Establishment and Person Level Phased Retirement Questions

\begin{tabular}{|c|c|c|c|c|c|c|c|c|c|}
\hline \multirow[t]{2}{*}{$\begin{array}{c}\text { Would } \\
\text { Establishment } \\
\text { Permit Phased } \\
\text { Retirement? } \\
\text { (Question 1) } \\
\end{array}$} & \multirow{2}{*}{$\begin{array}{l}\text { \# of Establish- } \\
\text { ments }\end{array}$} & \multirow{2}{*}{$\begin{array}{c}\text { \# of Establish- } \\
\text { ments with Info } \\
\text { on a Selected } \\
\text { Worker }\end{array}$} & \multirow[t]{2}{*}{$\begin{array}{l}\text { Phased } \\
\text { Retire- } \\
\text { ment not } \\
\text { Permit- } \\
\text { ted }\end{array}$} & \multicolumn{6}{|c|}{$\begin{array}{l}\text { Percent of Selected Workers in the Row for } \\
\text { Whom the Response to Question } 2 \text { was: }\end{array}$} \\
\hline & & & & "1" & "2" & "3" & "4" & "5" & Total \\
\hline yes & 639 & 556 & -- & $9.9 \%$ & $9.7 \%$ & $19.2 \%$ & $21.0 \%$ & $40.1 \%$ & $100.0 \%$ \\
\hline in some cases & 142 & 120 & -- & $17.5 \%$ & $16.7 \%$ & $25.8 \%$ & $18.3 \%$ & $21.7 \%$ & $100.0 \%$ \\
\hline no & 131 & 108 & $100.0 \%$ & -- & -- & -- & -- & -- & $100.0 \%$ \\
\hline na & 38 & 27 & $100.0 \%$ & -- & -- & -- & -- & -- & $100.0 \%$ \\
\hline Total & 950 & 811 & & & & & & & \\
\hline
\end{tabular}


Table 2

Characteristics of the Selected Worker and Feasibility of Phased Retirement in the Establishment and for the Individual

\begin{tabular}{|c|c|c|c|c|c|c|c|c|}
\hline \multirow[t]{4}{*}{ Characteristics of the Selected Worker (SW) } & \multicolumn{4}{|c|}{$\begin{array}{c}\text { Is Phased Retirement } \\
\text { Feasible in Establishment? }\end{array}$} & \multicolumn{4}{|c|}{$\begin{array}{c}\text { Is Phased Retirement } \\
\text { Feasible for Specific Worker? }\end{array}$} \\
\hline & \multirow{2}{*}{\multicolumn{2}{|c|}{$\begin{array}{l}\text { "Yes" } \\
(\mathrm{Y} 1=1) \\
\frac{\text { Stand }}{}\end{array}$}} & \multicolumn{2}{|c|}{$\begin{array}{l}\text { "No" } \\
(\mathrm{Y} 1=0)\end{array}$} & \multicolumn{2}{|c|}{$\begin{array}{c}\text { "Yes" } \\
(\mathrm{Y} 2=4,5)\end{array}$} & \multicolumn{2}{|c|}{$\begin{array}{c}\text { "No" } \\
(\mathrm{Y} 2=1,2)\end{array}$} \\
\hline & & & & Stand & & Stand & & Stand \\
\hline & $\frac{\text { Mean }}{(1)}$ & $\frac{\text { Error }}{(2)}$ & $\frac{\text { Mean }}{(3)}$ & $\frac{\text { Error }}{(4)}$ & $\frac{\text { Mean }}{(5)}$ & $\frac{\text { Error }}{(6)}$ & $\frac{\text { Mean }}{(7)}$ & $\frac{\text { Error }}{(8)}$ \\
\hline \multicolumn{9}{|l|}{ A. Demographic Characteristics of Selected Worker (SW) } \\
\hline (1) Age & 58.65 & 0.16 & 58.25 & 0.27 & $59.09^{s}$ & 0.23 & 57.75 & 0.23 \\
\hline (2) Education (years) & 15.02 & 0.08 & 15.30 & 0.18 & 14.84 & 0.10 & 15.07 & 0.16 \\
\hline (3) Health $(0=$ worst possible, $10=$ best possible $)$ & 7.67 & 0.07 & 7.68 & 0.16 & 7.70 & 0.10 & 7.43 & 0.16 \\
\hline (4) Gender $($ male $=1$, female $=0$ ) & 0.48 & 0.02 & 0.51 & 0.04 & 0.48 & 0.03 & 0.51 & 0.04 \\
\hline \multicolumn{9}{|l|}{ B. Performance of Selected Worker } \\
\hline \multicolumn{9}{|l|}{ Questions where $1=$ completely disagree; $5=$ completely agree } \\
\hline (6) Creative in solving problems on the job & 4.03 & 0.04 & 3.98 & 0.09 & $4.16^{s}$ & 0.05 & 3.80 & 0.09 \\
\hline (7) Willing to make extra effort to get job done & 4.39 & 0.03 & 4.33 & 0.09 & $4.51^{\mathrm{s}}$ & 0.04 & 4.17 & 0.08 \\
\hline (8) Gets along well with coworkers & 4.32 & 0.03 & 4.34 & 0.07 & 4.33 & 0.05 & 4.20 & 0.07 \\
\hline (9) Supervision required by SW (1=none, 4=a lot) & 2.39 & 0.03 & 2.43 & 0.06 & $2.27^{\mathrm{s}}$ & 0.04 & 2.58 & 0.06 \\
\hline (10) Number of hours worked by SW in a typical week & 42.67 & 0.30 & 42.36 & 0.61 & 42.37 & 0.41 & 42.88 & 0.58 \\
\hline (11) Regular annual salary before taxes (in thousands of \$) & 62.38 & 3.02 & 57.88 & 3.67 & 60.89 & 4.13 & 67.40 & 6.66 \\
\hline (12) Overall assessment of job performance $(0=$ low, $10=$ high $)$ & 7.85 & 0.06 & 7.83 & 0.13 & $8.03^{s}$ & 0.08 & 7.52 & 0.15 \\
\hline \multicolumn{9}{|l|}{ C. Occupation of SW } \\
\hline (13) Sales & 0.05 & 0.01 & 0.06 & 0.02 & 0.05 & 0.01 & 0.03 & 0.01 \\
\hline (14) Clerical & 0.20 & 0.02 & 0.17 & 0.03 & 0.21 & 0.02 & 0.17 & 0.03 \\
\hline (15) Professional & 0.38 & 0.02 & 0.43 & 0.04 & 0.40 & 0.02 & 0.35 & 0.04 \\
\hline (16) Manager & 0.37 & 0.02 & 0.34 & 0.04 & $0.34^{s}$ & 0.02 & 0.44 & 0.04 \\
\hline (17) Occ missing & 0.00 & 0.00 & 0.00 & 0.00 & 0.00 & 0.00 & 0.01 & 0.01 \\
\hline \multicolumn{9}{|l|}{ D. Job Characteristics Associated with Part-time Compatibility } \\
\hline (18) There are regular part-timers in SW's job title? $(1=y e s ; 0=$ no $)$ & $0.23 *$ & 0.02 & 0.04 & 0.02 & $0.30^{\mathrm{s}}$ & 0.02 & 0.11 & 0.03 \\
\hline Questions where $1=$ completely disagree; $5=$ completely agree & & & & & & & & \\
\hline (19) Job involves tasks that are discrete & 3.86 & 0.04 & 3.79 & 0.11 & 3.88 & 0.06 & 3.80 & 0.10 \\
\hline (20) Most tasks are performed alone & 3.18 & 0.05 & 3.34 & 0.11 & 3.24 & 0.06 & 3.06 & 0.10 \\
\hline
\end{tabular}

The difference between the means in columns 1 and 3 is statistically significant at a .05 level.

$s$ The difference between the means in columns 5 and 7 is statistically significant at a .05 level. 
Table 2 (contd.)

Characteristics of the Selected Worker and Feasibility of Phased Retirement in the Establishment and for the Individual

\begin{tabular}{|c|c|c|c|c|c|c|c|c|}
\hline \multirow[t]{5}{*}{ Characteristics of the Selected Worker (SW) } & \multicolumn{4}{|c|}{$\begin{array}{l}\text { Is Phased Retirement } \\
\text { Feasible in Establishment? }\end{array}$} & \multicolumn{4}{|c|}{$\begin{array}{c}\text { Is Phased Retirement } \\
\text { Feasible for Specific Worker? }\end{array}$} \\
\hline & \multirow{2}{*}{\multicolumn{2}{|c|}{$\begin{array}{l}\text { "Yes" } \\
(\mathrm{Y} 1=1) \\
\frac{\text { Stand }}{}\end{array}$}} & \multicolumn{2}{|c|}{$\begin{array}{l}\text { "No" } \\
(\mathrm{Y} 1=0)\end{array}$} & \multicolumn{2}{|c|}{$\begin{array}{c}\text { "Yes" } \\
(\mathrm{Y} 2=4,5)\end{array}$} & \multicolumn{2}{|c|}{$\begin{array}{l}\text { "No" } \\
(\mathrm{Y} 2=1,2)\end{array}$} \\
\hline & & & & Stand & & Stand & & Stand \\
\hline & Mean & Error & Mean & Error & Mean & Error & Mean & Error \\
\hline & $(1)$ & $\overline{(2)}$ & $(3)$ & $(4)$ & $(5)$ & $(6)$ & $(7)$ & $(8)$ \\
\hline (21)Job requires close communication with others & 4.55 & 0.03 & 4.56 & 0.06 & 4.53 & 0.04 & 4.54 & 0.06 \\
\hline E. Job Characteristics Associated with Specific Training & & & & & & & & \\
\hline (22) SW's Job tenure in establishment (years) & 14.37 & 0.35 & 14.91 & 0.81 & 14.55 & 0.48 & 14.88 & 0.75 \\
\hline (23) Employer sponsored training rarely or never occurs in SW's job & & & & & & & & \\
\hline $1=$ yes $($ rarely); $0=$ no & 0.20 & 0.02 & 0.21 & 0.03 & 0.19 & 0.02 & 0.24 & 0.04 \\
\hline F. Job Characteristics Associated with Skill Depreciation & & & & & & & & \\
\hline $\begin{array}{l}\text { (24) SW's job requires several years of experience to do well } \\
1=\text { completely disagree; } 5=\text { completely agree }\end{array}$ & 4.18 & 0.04 & 4.18 & 0.09 & 4.13 & 0.06 & 4.26 & 0.08 \\
\hline $\begin{array}{l}\text { (25) There are jobs where older workers are, on average, more } \\
\text { productive than younger workers. Other jobs are not that way. } \\
\text { How would you rate SW's job? }(1=\text { old much more productive } \\
\text { than young; } 5=\text { young more productive than old })\end{array}$ & $2.53 *$ & 0.03 & 2.71 & 0.08 & 2.49 & 0.04 & 2.64 & 0.07 \\
\hline G. Job Characteristics Associated with Difficulty in Finding a Replacement & & & & & & & & \\
\hline (26) There are contingent employees in SW's job title? $(1=y e s ; 0=$ no $)$ & 0.09 & 0.01 & 0.07 & 0.02 & 0.11 & 0.02 & 0.08 & 0.02 \\
\hline (27) If SW left job, how many months would it take to fill? & 2.51 & 0.11 & 2.64 & 0.20 & 2.76 & 0.18 & 2.35 & 0.16 \\
\hline (28) Increased difficulty finding employees for SW type job, past 5 yrs & & & & & & & & \\
\hline increased $(+1)$ stayed same $(0)$ decreased $(-1)$ & 0.35 & 0.03 & 0.36 & 0.06 & 0.39 & 0.03 & 0.31 & 0.06 \\
\hline H. Pension and Union Status of SW & & & & & & & & \\
\hline (29) Only covered by a DB pension & 0.23 & 0.02 & 0.30 & 0.04 & $0.19^{\Im}$ & 0.02 & 0.37 & 0.04 \\
\hline (30) Only covered by a DC pension & $0.51 *$ & 0.02 & 0.38 & 0.04 & $0.56^{\circledR}$ & 0.03 & 0.39 & 0.04 \\
\hline (31) Covered by both a DB and DC pension & 0.12 & 0.01 & 0.16 & 0.03 & 0.10 & 0.01 & 0.13 & 0.03 \\
\hline (32) Pension unclear ${ }^{a}$ & $0.04 *$ & 0.01 & 0.09 & 0.02 & 0.04 & 0.01 & 0.03 & 0.01 \\
\hline (33) Not covered by a pension & 0.10 & 0.01 & 0.07 & 0.02 & 0.12 & 0.02 & 0.09 & 0.02 \\
\hline (34) Is SW's job covered by union contract? $(1=$ yes; $0=$ no $)$ & $0.12 *$ & 0.01 & 0.24 & 0.04 & $0.11^{\mathrm{s}}$ & 0.02 & 0.22 & 0.03 \\
\hline
\end{tabular}

a. "pension unclear" indicates that the respondent was uncertain about whether the pension plan was a defined contribution or defined benefit plan, and despite our best efforts, we were unable to clarify matters.

* The difference between the means in columns 1 and 3 is statistically significant at a .05 level.

$\checkmark$ The difference between the means in columns 5 and 7 is statistically significant at a .05 level. 
Table 3a

Employer Response to Question about Phased Retirement for the Selected Worker :

Models Estimated with Ordered Probit on a Dependent Variable that Takes Values 1 through 5

\begin{tabular}{|c|c|c|c|c|c|c|}
\hline \multirow[b]{2}{*}{ Variable Name } & \multicolumn{2}{|c|}{$\underline{\text { Model } 1}$} & \multicolumn{2}{|c|}{ Model 2} & \multicolumn{2}{|c|}{$\underline{\text { Model } 3}$} \\
\hline & Coeff. & $\mathbf{t}$ & Coeff. & $\mathbf{t}$ & Coeff. & $\mathbf{t}$ \\
\hline \multicolumn{7}{|l|}{ Demographic Characteristics of Selected Worker } \\
\hline Age & 0.0448 & $(3.5)$ & 0.0419 & $(3.3)$ & 0.0407 & $(3.3)$ \\
\hline Education (years) & -0.0132 & $(0.6)$ & -0.0132 & $(0.6)$ & -0.0242 & $(1.1)$ \\
\hline Health $(0=$ worst possible, $10=$ best possible $)$ & 0.0475 & $(2.0)$ & 0.0156 & $(0.6)$ & 0.0061 & $(0.2)$ \\
\hline Gender $($ male $=1$, female $=0)$ & -0.0473 & $(0.6)$ & -0.0407 & $(0.5)$ & -0.0660 & $(0.8)$ \\
\hline \multicolumn{7}{|l|}{ Job Performance of SW } \\
\hline Overall assessment $(0=$ low, $10=$ high $)$ & & & 0.0837 & $(3.0)$ & 0.0190 & $(0.5)$ \\
\hline Learns new procedures and technologies & & & & & 0.0052 & $(0.1)$ \\
\hline Creative in solving problems on the job & & & & & 0.0837 & $(1.4)$ \\
\hline Willing to make extra effort to get job done & & & & & 0.1548 & $(2.4)$ \\
\hline Gets along well with coworkers & & & & & -0.0783 & $(1.4)$ \\
\hline Supervision required by $\mathrm{SW}(1=$ none, $4=\mathrm{a}$ lot $)$ & & & & & -0.1794 & $(3.3)$ \\
\hline Model Includes Variables in Table 3b Model 4 & NO & & NO & & NO & \\
\hline Model Includes Establishment Level Variables & NO & & NO & & NO & \\
\hline \multicolumn{7}{|l|}{ Cutpoints } \\
\hline Cut 1 & 1.6367 & & 1.8725 & & 1.3909 & \\
\hline Cut 2 & 2.1125 & & 2.3502 & & 1.8749 & \\
\hline Cut 3 & 2.7108 & & 2.9531 & & 2.4927 & \\
\hline Cut 4 & 3.2889 & & 3.5365 & & 3.0930 & \\
\hline Log Likelihood & -1180.93 & & -1175.72 & & -1159.97 & \\
\hline Pseudo R Square & 0.01 & & 0.02 & & 0.03 & \\
\hline Number of Observations & 796 & & 796 & & 796 & \\
\hline
\end{tabular}


Table 3a (continued)

Employer Response to Question about Phased Retirement for the Selected Worker :

Models Estimated with Ordered Probit on a Dependent Variable that Takes Values 1 through 5

\begin{tabular}{|c|c|c|c|c|}
\hline \multirow[b]{2}{*}{ Variable Name } & \multicolumn{2}{|c|}{ Model 4} & \multicolumn{2}{|c|}{ Model 5} \\
\hline & Coeff. & $\mathbf{t}$ & Coeff. & $\mathbf{t}$ \\
\hline \multicolumn{5}{|l|}{ Demographic Characteristics of Selected Worker } \\
\hline Age & 0.0403 & $(3.2)$ & 0.0413 & $(3.4)$ \\
\hline Education (years) & -0.0023 & $(0.1)$ & -0.0001 & $(0.0)$ \\
\hline Health $(0=$ worst possible, $10=$ best possible $)$ & 0.0077 & $(0.3)$ & 0.0180 & $(0.7)$ \\
\hline Gender $($ male $=1$, female $=0)$ & -0.0315 & $(0.3)$ & -0.0647 & $(0.7)$ \\
\hline \multicolumn{5}{|l|}{ Job Performance of SW } \\
\hline Overall assessment $(0=$ low, $10=$ high $)$ & 0.0206 & $(0.6)$ & 0.0074 & $(0.2)$ \\
\hline Learns new procedures and technologies & 0.0324 & $(0.6)$ & 0.0309 & $(0.5)$ \\
\hline Creative in solving problems on the job & 0.0674 & $(1.0)$ & 0.0907 & $(1.4)$ \\
\hline Willing to make extra effort to get job done & 0.1445 & $(2.1)$ & 0.1587 & $(2.3)$ \\
\hline Gets along well with coworkers & -0.0885 & (1.6) & -0.0761 & $(1.3)$ \\
\hline Supervision required by $S W(1=$ none, $4=a$ lot $)$ & -0.1824 & $(3.2)$ & -0.1685 & $(2.9)$ \\
\hline Model Includes Variables in Table 3b Model 4 & YES & & YES & \\
\hline Model Includes Establishment Level Variables & NO & & YES & \\
\hline \multicolumn{5}{|l|}{ Cutpoints } \\
\hline Cut 1 & 0.9980 & & 1.1852 & \\
\hline Cut 2 & 1.5136 & & 1.7311 & \\
\hline Cut 3 & 2.1714 & & 2.4243 & \\
\hline Cut 4 & 2.8045 & & 3.0888 & \\
\hline Log Likelihood & -1122.82 & & -1088.21 & \\
\hline Pseudo R Square & 0.06 & & 0.09 & \\
\hline Number of Observations & 796 & & 796 & \\
\hline
\end{tabular}


Table $3 b$

Employer Response to Question about Phased Retirement for the Selected Worker :

Models Estimated with Ordered Probit on a Dependent Variable that Takes Values 1 through 5

\begin{tabular}{|c|c|c|c|c|c|c|}
\hline \multirow[b]{2}{*}{ Variable Name } & \multicolumn{2}{|c|}{ Model 1} & \multicolumn{2}{|c|}{ Model 2} & \multicolumn{2}{|c|}{ Model 3} \\
\hline & Coeff. & $\mathbf{t}$ & Coeff. & $\mathbf{t}$ & Coeff. & $\mathbf{t}$ \\
\hline \multicolumn{7}{|l|}{ Occupation of Selected Worker ${ }^{a}$} \\
\hline Professional & -0.0776 & $(0.4)$ & -0.0858 & $(0.4)$ & 0.0085 & $(0.0)$ \\
\hline Manager & -0.1848 & $(0.9)$ & -0.1437 & $(0.7)$ & -0.1058 & $(0.5)$ \\
\hline Clerical & 0.0089 & $(0.0)$ & 0.0327 & $(0.2)$ & 0.1117 & $(0.5)$ \\
\hline \multicolumn{7}{|l|}{ Characteristics of SW's Job } \\
\hline \multicolumn{7}{|l|}{ Job is Compatible with Part-time Work } \\
\hline There are regular part-timers in SW's job title & & & 0.5167 & $(4.7)$ & 0.5239 & $(4.8)$ \\
\hline Job involves tasks that are discrete & & & 0.0432 & $(1.2)$ & 0.0421 & $(1.1)$ \\
\hline Most tasks are performed alone & & & 0.0381 & (1.1) & 0.0319 & $(0.9)$ \\
\hline Job requires close communication with others & & & 0.0919 & (1.6) & 0.0772 & $(1.3)$ \\
\hline \multicolumn{7}{|l|}{ Skill and Training } \\
\hline Employer-sponsored training rarely or never occurs & & & -0.1066 & $(1.1)$ & -0.1568 & $(1.6)$ \\
\hline Job where young are more productive than old & & & -0.1446 & $(2.5)$ & -0.1242 & $(2.2)$ \\
\hline Job requires several years of experience to do well & & & -0.0503 & $(1.2)$ & -0.0409 & $(0.9)$ \\
\hline SW's job tenure in establishment & & & -0.0010 & $(0.2)$ & 0.0044 & $(0.9)$ \\
\hline \multicolumn{7}{|l|}{ Difficulty in Finding a Replacement } \\
\hline There are contingent employees in SW's job title? & & & -0.0439 & $(0.3)$ & 0.0165 & $(0.1)$ \\
\hline If SW left job, how many months would it take to fill? & & & 0.0378 & $(2.3)$ & 0.0379 & $(2.2)$ \\
\hline Increased Difficulty finding employees for SW type job & & & 0.0431 & $(0.7)$ & 0.0443 & $(0.7)$ \\
\hline \multicolumn{7}{|l|}{ Pension ${ }^{\mathrm{a}}$ and Union Status of SW's Job } \\
\hline Only covered by a DB pension & & & & & -0.3785 & $(3.5)$ \\
\hline Covered by both a DB and DC pension & & & & & -0.4593 & (3.4) \\
\hline Pension unclear & & & & & -0.1411 & $(0.6)$ \\
\hline Not covered by a pension & & & & & -0.0924 & $(0.7)$ \\
\hline Is $S W$ 's job covered by union contract? $(1=$ yes; $0=$ no $)$ & & & & & -0.3889 & $(3.0)$ \\
\hline Model Includes Variables in Table 3a Model 4 & NO & & NO & & NO & \\
\hline Model Includes Establishment Level Variables & NO & & NO & & NO & \\
\hline \multicolumn{7}{|l|}{ Cutpoints } \\
\hline Cut 1 & -1.3544 & & -1.0675 & & -1.1569 & \\
\hline Cut 2 & -0.8860 & & -0.5826 & & -0.6564 & \\
\hline Cut 3 & -0.2962 & & 0.0306 & & -0.0248 & \\
\hline Cut 4 & 0.2720 & & 0.6220 & & 0.5795 & \\
\hline Log Likelihood & -1193.42 & & -1167.30 & & -1150.69 & \\
\hline Pseudo R Square & 0.00 & & 0.02 & & 0.04 & \\
\hline Number of Observations & 796 & & 796 & & 796 & \\
\hline
\end{tabular}

${ }^{\mathrm{a}}$ The excluded occupation is sales and the excluded pension is defined contribution. 
Table $3 b$ (continued)

Employer Response to Question about Phased Retirement for the Selected Worker :

Models Estimated with Ordered Probit on a Dependent Variable that Takes Values 1 through 5

\begin{tabular}{|c|c|c|c|c|}
\hline \multirow[b]{2}{*}{ Variable Name } & \multicolumn{2}{|c|}{ Model 4} & \multicolumn{2}{|c|}{ Model 5} \\
\hline & Coeff. & $\mathbf{t}$ & Coeff. & $\mathbf{t}$ \\
\hline \multicolumn{5}{|l|}{ Occupation of Selected Worker ${ }^{\mathrm{a}}$} \\
\hline Professional & -0.0641 & $(0.3)$ & -0.0471 & $(0.2)$ \\
\hline Manager & -0.1773 & $(0.9)$ & -0.1428 & $(0.7)$ \\
\hline Clerical & 0.0972 & $(0.4)$ & 0.1255 & $(0.5)$ \\
\hline \multicolumn{5}{|l|}{ Characteristics of SW's Job } \\
\hline \multicolumn{5}{|l|}{ Job is Compatible with Part-time Work } \\
\hline There are regular part-timers in SW's job title & 0.5239 & $(4.7)$ & 0.5130 & $(4.3)$ \\
\hline Job involves tasks that are discrete & 0.0311 & $(0.8)$ & 0.0350 & $(0.9)$ \\
\hline Most tasks are performed alone & 0.0043 & $(0.1)$ & 0.0106 & $(0.3)$ \\
\hline Job requires close communication with others & 0.0071 & $(0.1)$ & -0.0273 & $(0.4)$ \\
\hline \multicolumn{5}{|l|}{ Skill and Training } \\
\hline Employer-sponsored training rarely or never occurs & -0.2271 & $(2.2)$ & -0.2319 & $(2.1)$ \\
\hline Job where young are more productive than old & -0.0814 & $(1.4)$ & -0.0723 & $(1.2)$ \\
\hline Job requires several years of experience to do well & -0.0664 & $(1.5)$ & -0.0723 & $(1.5)$ \\
\hline SW's job tenure in establishment & 0.0024 & $(0.5)$ & 0.0098 & (1.9) \\
\hline \multicolumn{5}{|l|}{ Difficulty in Finding a Replacement } \\
\hline There are contingent employees in SW's job title & 0.0826 & $(0.5)$ & 0.0780 & $(0.4)$ \\
\hline If SW left job, how many months would it take to fill? & 0.0245 & $(1.3)$ & 0.0265 & (1.4) \\
\hline Increased Difficulty finding employees for SW type job & 0.0170 & $(0.3)$ & -0.0341 & $(0.5)$ \\
\hline \multicolumn{5}{|l|}{ Pension a and Union Status of SW's Job } \\
\hline Only covered by a DB pension & -0.3439 & $(3.1)$ & -0.2181 & $(1.4)$ \\
\hline Covered by both a DB and DC pension & -0.4461 & $(3.3)$ & -0.1610 & $(1.0)$ \\
\hline Pension unclear & -0.1898 & $(0.8)$ & -0.0292 & $(0.1)$ \\
\hline Not covered by a pension & -0.1221 & $(0.9)$ & -0.1155 & $(0.6)$ \\
\hline Is $S W$ 's job covered by union contract? $(1=\mathrm{yes} ; 0=\mathrm{no})$ & -0.2625 & $(2.0)$ & -0.1094 & $(0.5)$ \\
\hline Model Includes Variables in Table 3a Model 4 & YES & & YES & \\
\hline Model Includes Establishment Level Variables & NO & & YES & \\
\hline \multicolumn{5}{|l|}{ Cutpoints } \\
\hline Cut 1 & 0.9980 & & 1.1852 & \\
\hline Cut 2 & 1.5136 & & 1.7311 & \\
\hline Cut 3 & 2.1714 & & 2.4243 & \\
\hline Cut 4 & 2.8045 & & 3.0888 & \\
\hline Log Likelihood & -1122.82 & & -1088.21 & \\
\hline Pseudo R Square & 0.06 & & 0.09 & \\
\hline Number of Observations & 796 & & 796 & \\
\hline
\end{tabular}

\footnotetext{
${ }^{a}$ The excluded occupation is sales and the excluded pension is defined contribution.
} 


\title{
Appendix A: Description of Survey Variables
}

\author{
Demographic and Performance Characteristics of the Selected Worker
}

The survey respondents were asked for their best estimate of the age (in years), gender, and highest level of schooling (some high school, but did not graduate; high school graduate or GED, ..., graduate work or degree). Information on health status was obtained with the following question:

-- On a scale from 0 to 10 where 0 indicates the worst possible health and 10 indicates the best possible health, how would you rate (name's) overall health.

The subsequent description of variables assumes that the selected worker is female. Of course, the same questions were asked for males, but with different pronouns.

With regard to performance, the question on overall job performance took the form, "on a scale from 0 to 10 , where 0 means the worst possible employee and 10 means the best possible employee, how would you rate (name's) job performance." With regard to specific dimensions of performance, the following question, which appears in Table 2 as variable 9, probed the amount of supervision required by the selected worker:

-- How closely is (name) supervised as she does her work? Would you say (name) has no supervision, a little supervision, some supervision, or a lot of supervision? ${ }^{28}$

We also posed the following questions, which appear in Table 2 as variables $5-8$,

-- Thinking about (name), please respond to the following statements using a scale from 1

to 5 , where 1 indicates that you completely disagree with the statement and 5 indicates that you completely agree with the statement. ${ }^{29}$

(a) (name) easily learns new procedures and technologies when they are introduced in the workplace.

(b) (name) is creative in solving problems on the job.

(c) (name) is willing to put forth extra effort to get the job done.

(d) (name) gets along well with coworkers.

Finally, information was gathered on usual weekly hours and annual salary (Table 2 variables 10 and 11) as follows:

-- In a typical week, how many hours does (name) work on this job.

-- What is your best estimate of (name's) regular annual salary or wages, before taxes and deductions, not including overtime and bonuses.

\section{Job Characteristics}

To obtain information on the selected workers' occupation (Table 2, variables 13 - 17), the respondent was asked which of the following occupational categories best describe (name)'s position: professional (including technical), manager or administrator, sales personnel, clerical or office worker. In addition, we asked if any of the employees with (name)'s job title are employed as regular part-time employees, that is, scheduled to work fewer than 35 hour per week (Table 2 variable 18), as well as the following question (which yields Table 2 variables $19-21$ and 24):

-- Thinking about (name), please respond to the following statements using a scale from 1 to 5 , where 1 indicates that you completely disagree with the statement and 5 indicates that you completely agree with the statement.

(a) her job involves tasks that are discrete, in the sense that they have a clear beginning and end, and are relatively self contained.

(b) her job requires that (name) perform most tasks alone. 
(c) her job requires frequent or close communication with other members of a group.

(d) In general, her job requires several years of experience to do well.

Additional data on job tenure, training, and skill depreciation (Table 2 variables 22, 23, 25) come from the following:

-- About how many years has (name) worked for your establishment? (fewer than 5 years, 5-10 years, 11-15 years, $16-26$ years, $25+$ years).

-- Some jobs involve skills that need regular updating through employer-sponsored training. How often would you say that a typical individual in (name)'s job receives employer-sponsored training - would you say often, sometimes, rarely or never.

-- There are some jobs where, on average, older workers tend to be much more productive than younger workers. There are other jobs where this is not true. How would you rate the job of (name) - on average, would you say older workers are:

$<1>$ much more productive than younger workers in this job?

$<2>$ moderately more productive than younger workers in this job?

... etc.

Data on difficulty finding a replacement (Table 2 variables 26 - 28) come from a question on whether there are contract or temporary workers in (name)'s job title, and the following:

-- If (name) were to leave this job and your organization decided to recruit someone from outside to replace her, about how long would it take to hire someone to take her place? (respondent answered both number and units, e.g., days, weeks, months)

-- Compared to 5 years ago, would you say it is now more difficult, less difficult, or about as difficult to find employees to fill position like (name)'s?

Pensions and Union Status

Since the literature on phased retirement stressed pensions, considerable effort went into survey questions that would determine the pension characteristics of both the establishment and the selected worker. Respondents were asked whether white-collar workers age 55 and over were covered by a traditional defined benefit plan, a cash balance plan, a defined contribution plan, or something else. In addition, respondents were given a list of possible pension types (401-K, ESOP, and so on). Given this information, we made our own assessment of whether the establishment had a defined benefit or defined contribution plan. For example, if the respondent told us that the pension was a cash balance plan, then regardless of what the respondent said about it being a defined benefit or defined contribution, the pension was classified as a defined benefit plan. Having determined the set of pensions existing in the establishment, it was straightforward to determine whether and how the selected worker was covered.

Finally, Union status was ascertained with the question: Is (name's) job covered by a union or employee-association contract? 


\section{Appendix B. Multivariate Results with Listwise Deletion}

The following tables $4 \mathrm{a}$ and $4 \mathrm{~b}$ are identical to $3 \mathrm{a}$ and $3 \mathrm{~b}$ in the text, except that $3 \mathrm{a}$ and $3 \mathrm{~b}$ utilize multiple imputation while $4 \mathrm{a}$ and $4 \mathrm{~b}$ utilize listwise deletion.

Appendix Table 4a

Employer Response to Question about Phased Retirement for the Selected Worker : Models Estimated with Ordered Probit on a Dependent Variable that Takes Values 1 through 5. Listwise Deletion Applied

\begin{tabular}{|c|c|c|c|c|c|c|}
\hline \multirow[b]{2}{*}{ Variable Name } & \multicolumn{2}{|c|}{ Model 1} & \multicolumn{2}{|c|}{ Model 2} & \multicolumn{2}{|c|}{ Model 3} \\
\hline & Coeff. & $\mathbf{t}$ & Coeff. & $\mathbf{t}$ & Coeff. & $\mathbf{t}$ \\
\hline \multicolumn{7}{|l|}{ Demographic Characteristics of Selected Worker } \\
\hline Age & 0.0504 & (3.4) & 0.0470 & $(3.2)$ & 0.0434 & $(2.8)$ \\
\hline Education (years) & -0.0237 & $(0.9)$ & -0.0233 & $(0.9)$ & -0.0353 & $(1.3)$ \\
\hline Health $(0=$ worst possible, $10=$ best possible $)$ & 0.0091 & $(0.3)$ & -0.0228 & $(0.7)$ & -0.0320 & $(1.0)$ \\
\hline Gender $($ male $=1$, female $=0)$ & -0.0386 & $(0.4)$ & -0.0359 & $(0.3)$ & -0.0619 & $(0.6)$ \\
\hline \multicolumn{7}{|l|}{ Job Performance of SW } \\
\hline Overall assessment $(0=$ low, $10=$ high $)$ & & & 0.0846 & $(2.2)$ & -0.0048 & $(0.1)$ \\
\hline Learns new procedures and technologies & & & & & 0.0263 & $(0.4)$ \\
\hline Creative in solving problems on the job & & & & & 0.0521 & $(0.7)$ \\
\hline Willing to make extra effort to get job done & & & & & 0.1770 & $(2.1)$ \\
\hline Gets along well with coworkers & & & & & -0.0476 & $(0.7)$ \\
\hline Supervision required by SW (1=none, $4=\mathrm{a}$ lot) & & & & & -0.2568 & (3.7) \\
\hline Model Includes Variables in Table 5b Model 4 & NO & & NO & & NO & \\
\hline Model Includes Establishment Level Variables & NO & & NO & & NO & \\
\hline \multicolumn{7}{|l|}{ Cutpoints } \\
\hline Cut 1 & 1.6811 & & 1.8942 & & 1.0800 & \\
\hline Cut 2 & 2.1220 & & 2.3350 & & 1.5323 & \\
\hline Cut 3 & 2.6821 & & 2.8975 & & 2.1164 & \\
\hline Cut 4 & 3.1897 & & 3.4102 & & 2.6484 & \\
\hline Log Likelihood & -647.02 & & -644.5 & & -632.75 & \\
\hline Pseudo R Square & 0.01 & & 0.01 & & 0.03 & \\
\hline Number of Observations & 437 & & 437 & & 437 & \\
\hline
\end{tabular}


Appendix Table 4a (Continued)

Employer Response to Question about Phased Retirement for the Selected Worker : Models Estimated with Ordered Probit on a Dependent Variable that Takes Values 1 through 5. Listwise Deletion Applied

\begin{tabular}{|c|c|c|c|c|}
\hline & Model 4 & & Model 5 & \\
\hline Variable Name & Coeff. & $\mathbf{t}$ & Coeff. & $\mathbf{t}$ \\
\hline \multicolumn{5}{|l|}{ Demographic Characteristics of Selected Worker } \\
\hline Age & 0.0351 & $(2.2)$ & 0.0348 & $(2.0)$ \\
\hline Education (years) & -0.0051 & $(0.2)$ & 0.0113 & $(0.3)$ \\
\hline Health $(0=$ worst possible, $10=$ best possible $)$ & -0.0339 & $(1.0)$ & -0.0141 & $(0.4)$ \\
\hline Gender $($ male $=1$, female $=0)$ & -0.0247 & $(0.2)$ & 0.0088 & $(0.1)$ \\
\hline \multicolumn{5}{|l|}{ Job Performance of SW } \\
\hline Overall assessment $(0=$ low, $10=$ high $)$ & -0.0021 & $(0.0)$ & -0.0224 & $(0.4)$ \\
\hline Learns new procedures and technologies & 0.0676 & $(1.0)$ & 0.0500 & $(0.7)$ \\
\hline Creative in solving problems on the job & 0.0282 & $(0.4)$ & 0.0136 & $(0.2)$ \\
\hline Willing to make extra effort to get job done & 0.1885 & $(2.1)$ & 0.2596 & $(2.8)$ \\
\hline Gets along well with coworkers & -0.0343 & $(0.5)$ & 0.0051 & $(0.1)$ \\
\hline Supervision required by $S W(1=$ none, $4=a$ lot $)$ & -0.2907 & (3.9) & -0.2835 & $(3.6)$ \\
\hline Model Includes Variables in Table 5b Model 4 & YES & & YES & \\
\hline Model Includes Establishment Level Variables & NO & & YES & \\
\hline \multicolumn{5}{|l|}{ Cutpoints } \\
\hline Cut 1 & 0.7513 & & 0.2056 & \\
\hline Cut 2 & 1.2310 & & 0.7348 & \\
\hline Cut 3 & 1.8531 & & 1.4087 & \\
\hline Cut 4 & 2.4174 & & 2.0145 & \\
\hline Log Likelihood & -611.89 & & -582.77 & \\
\hline Pseudo R Square & 0.06 & & 0.11 & \\
\hline Number of Observations & 437 & & 437 & \\
\hline
\end{tabular}


Appendix Table $4 b$

Employer Response to Question about Phased Retirement for the Selected Worker : Models Estimated with Ordered Probit on a Dependent Variable that Takes Values 1 through 5. Listwise Deletion Applied

\begin{tabular}{|c|c|c|c|c|c|c|}
\hline \multirow[b]{2}{*}{ Variable Name } & \multicolumn{2}{|c|}{ Model 1} & \multicolumn{2}{|c|}{ Model 2} & \multicolumn{2}{|c|}{ Model 3} \\
\hline & Coeff. & $\mathbf{t}$ & Coeff. & $\mathbf{t}$ & Coeff. & $\mathbf{t}$ \\
\hline \multicolumn{7}{|l|}{ Occupation of Selected Worker ${ }^{\mathrm{a}}$} \\
\hline Professional & -0.1909 & $(0.6)$ & -0.2939 & $(1.0)$ & -0.1841 & $(0.6)$ \\
\hline Manager & -0.2931 & $(1.0)$ & -0.3442 & $(1.1)$ & -0.2919 & $(0.9)$ \\
\hline Clerical & -0.0114 & $(0.0)$ & -0.0791 & $(0.3)$ & 0.0064 & $(0.0)$ \\
\hline \multicolumn{7}{|l|}{ Characteristics of SW's Job } \\
\hline \multicolumn{7}{|l|}{ Job is Compatible with Part-time Work } \\
\hline There are regular part-timers in SW's job title & & & 0.4598 & $(3.2)$ & 0.4354 & $(3.0)$ \\
\hline Job involves tasks that are discrete & & & 0.0484 & $(1.0)$ & 0.0531 & $(1.1)$ \\
\hline Most tasks are performed alone & & & 0.0215 & $(0.5)$ & 0.0145 & $(0.3)$ \\
\hline Job requires close communication with others & & & 0.1331 & (1.6) & 0.1222 & $(1.5)$ \\
\hline \multicolumn{7}{|l|}{ Skill and Training } \\
\hline Employer-sponsored training rarely or never occurs & & & -0.1498 & $(1.1)$ & -0.2180 & $(1.6)$ \\
\hline Job where young are more productive than old & & & -0.0550 & $(0.8)$ & -0.0406 & $(0.6)$ \\
\hline Job requires several years of experience to do well & & & -0.0444 & $(0.8)$ & -0.0486 & $(0.8)$ \\
\hline SW's job tenure in establishment & & & 0.0069 & $(1.2)$ & 0.0132 & $(2.2)$ \\
\hline \multicolumn{7}{|l|}{ Difficulty in Finding a Replacement } \\
\hline There are contingent employees in SW's job title? & & & 0.0522 & $(0.3)$ & 0.1607 & $(0.8)$ \\
\hline If SW left job, how many months would it take to fill? & & & 0.0542 & $(2.3)$ & 0.0530 & $(2.3)$ \\
\hline Increased Difficulty finding employees for SW type job & & & -0.0149 & $(0.2)$ & -0.0126 & $(0.2)$ \\
\hline \multicolumn{7}{|l|}{ Pension a and Union Status of SW's Job } \\
\hline Only covered by a DB pension & & & & & -0.1355 & $(1.0)$ \\
\hline Covered by both a DB and DC pension & & & & & -0.3975 & $(2.3)$ \\
\hline Pension unclear & & & & & -0.1225 & $(0.5)$ \\
\hline Not covered by a pension & & & & & 0.2218 & $(1.1)$ \\
\hline Is $S W$ 's job covered by union contract? $(1=$ yes; $0=$ no $)$ & & & & & -0.5023 & $(2.9)$ \\
\hline Model Includes Variables in Table 5a Model 4 & NO & & NO & & NO & \\
\hline Model Includes Establishment Level Variables & NO & & NO & & NO & \\
\hline \multicolumn{7}{|l|}{ Cutpoints } \\
\hline Cut 1 & -1.3888 & & -0.6586 & & -0.6761 & \\
\hline Cut 2 & -0.9517 & & -0.2068 & & -0.2122 & \\
\hline Cut 3 & -0.3936 & & 0.3745 & & 0.3795 & \\
\hline Cut 4 & 0.1080 & & 0.8963 & & 0.9113 & \\
\hline Log Likelihood & -651.79 & & -638.43 & & -630.09 & \\
\hline Pseudo R Square & 0 & & 0.02 & & 0.04 & \\
\hline Number of Observations & 437 & & 437 & & 437 & \\
\hline
\end{tabular}

\footnotetext{
${ }^{a}$ The excluded occupation is sales and the excluded pension is defined contribution.
} 
Appendix Table $4 \mathrm{~b}$ (Continued)

Employer Response to Question about Phased Retirement for the Selected Worker : Models Estimated with Ordered Probit on a Dependent Variable that Takes

Values 1 through 5. Listwise Deletion Applied

\begin{tabular}{|c|c|c|c|c|}
\hline \multirow[b]{2}{*}{ Variable Name } & \multicolumn{2}{|c|}{ Model 4} & \multicolumn{2}{|c|}{ Model 5} \\
\hline & Coeff. & $\mathbf{t}$ & Coeff. & $\mathbf{t}$ \\
\hline \multicolumn{5}{|l|}{ Occupation of Selected Worker ${ }^{\mathrm{a}}$} \\
\hline Professional & -0.2379 & $(0.7)$ & 0.1128 & $(0.3)$ \\
\hline Manager & -0.3857 & $(1.2)$ & -0.0709 & $(0.2)$ \\
\hline Clerical & -0.0022 & $(0.0)$ & 0.3866 & $(1.0)$ \\
\hline \multicolumn{5}{|l|}{ Characteristics of SW's Job } \\
\hline \multicolumn{5}{|l|}{ Job is Compatible with Part-time Work } \\
\hline There are regular part-timers in SW's job title & 0.4159 & $(2.8)$ & 0.4384 & $(2.8)$ \\
\hline Job involves tasks that are discrete & 0.0377 & $(0.8)$ & 0.0339 & $(0.6)$ \\
\hline Most tasks are performed alone & -0.0275 & $(0.6)$ & -0.0079 & $(0.2)$ \\
\hline Job requires close communication with others & 0.0649 & $(0.7)$ & 0.0189 & $(0.2)$ \\
\hline \multicolumn{5}{|l|}{ Skill and Training } \\
\hline Employer-sponsored training rarely or never occurs & -0.2990 & $(2.1)$ & -0.3340 & $(2.2)$ \\
\hline Job where young are more productive than old & -0.0013 & $(0.0)$ & 0.0432 & $(0.6)$ \\
\hline Job requires several years of experience to do well & -0.0818 & $(1.4)$ & -0.1052 & $(1.6)$ \\
\hline SW's job tenure in establishment & 0.0132 & $(2.1)$ & 0.0222 & $(3.1)$ \\
\hline \multicolumn{5}{|l|}{ Difficulty in Finding a Replacement } \\
\hline There are contingent employees in SW's job title & 0.1948 & $(0.9)$ & 0.1186 & $(0.5)$ \\
\hline If SW left job, how many months would it take to fill? & 0.0273 & $(1.1)$ & 0.0170 & $(0.7)$ \\
\hline Increased Difficulty finding employees for SW type job & -0.0229 & $(0.3)$ & -0.0777 & $(0.9)$ \\
\hline \multicolumn{5}{|l|}{ Pension a and Union Status of SW's Job } \\
\hline Only covered by a DB pension & -0.1009 & $(0.7)$ & 0.1728 & $(0.8)$ \\
\hline Covered by both a DB and DC pension & -0.4032 & $(2.3)$ & 0.0034 & $(0.0)$ \\
\hline Pension unclear & -0.1766 & $(0.6)$ & 0.0491 & $(0.2)$ \\
\hline Not covered by a pension & 0.2294 & $(1.1)$ & 0.1189 & $(0.3)$ \\
\hline Is $S W$ 's job covered by union contract? $(1=$ yes; $0=$ no $)$ & -0.3908 & $(2.2)$ & -0.3891 & $(1.2)$ \\
\hline Model Includes Variables in Table 5a Model 4 & YES & & YES & \\
\hline Model Includes Establishment Level Variables & NO & & YES & \\
\hline \multicolumn{5}{|l|}{ Cutpoints } \\
\hline Cut 1 & 0.7513 & & 0.2056 & \\
\hline Cut 2 & 1.2310 & & 0.7348 & \\
\hline Cut 3 & 1.8531 & & 1.4087 & \\
\hline Cut 4 & 2.4174 & & 2.0145 & \\
\hline Log Likelihood & -611.89 & & -582.77 & \\
\hline Pseudo R Square & 0.06 & & 0.11 & \\
\hline Number of Observations & 437 & & 437 & \\
\hline
\end{tabular}

\footnotetext{
${ }^{a}$ The excluded occupation is sales and the excluded pension is defined contribution.
} 


\section{Endnotes}

${ }^{1}$ For example, Committee for Economic Development (1999) or AARP (1999)
${ }^{2}$ See Quinn, Burkhauser, and Meyers (1990), and Ruhm (1990).
${ }^{3}$ For example, Chen (2003).
${ }^{4}$ United States General Accounting Office (2001), p. 27.
${ }^{5}$ Blue collar and white collar workers often have different work arrangements and pensions. A thorough
treatment of both blue and white collar workers would have required a longer survey and resulted in lower response rates.

${ }^{6}$ Of course, if the respondent did not know of three older men (women) in the establishment, we accepted the other gender.

${ }^{7}$ The approach is similar to studies of a focal child in research on families. Why not two names? Since we could not draw true random pairs within the establishment (employers do not readily provide researchers with lists of employees), and since interviews with employers must be kept short, we sought in-depth information on one employee rather than a few questions on two.

8 This simplifies matters to facilitate exposition. In reality we asked two questions: one regarding shifting to a part-time work schedule before official retirement and the other regarding a part-time work schedule after official retirement.

${ }^{9}$ For example, data collected from establishments are unlikely to include accurate information on employee wealth or living arrangements. A study of when phased retirements actually occur would ideally utilize linked employer-employee data.

It is important to point out, however, that when in answering Q1 the respondent said that phased retirement could be worked out, there had often been actual cases of phased retirement in the establishment. When respondents said that phased retirement could be worked out, we asked whether in the last three years a white-collar worker age 55 or over had actually shifted from a full-time to a part-time work schedule. Fully $42 \%$ said "yes." This percentage should arguably increase with establishment size. Small establishments may employ only a handful of people over 55; if none are interest in phased retirement, then regardless of the opportunity, the right answer to our question would be "no." That is less likely in large establishments with their larger numbers of people over 55. It turns out that the percentage is in fact higher in large establishments. For establishments with 500 or more (less) employees, the percentage is $77 \%$. (39\%).

${ }^{10}$ More formally, the problem is $\underset{h_{j}, W_{j}^{1}(H), W_{j}^{2}\left(h_{j}\right)}{\operatorname{Max}} \sum_{j=1,2} f\left(h_{j}, \theta_{j}\right)-\left(T_{j}+W_{j}^{1}(H)+W_{j}^{2}\left(h_{j}\right)\right)$,

subject to $W_{j}^{1}(H)+W_{j}^{2}\left(h_{j}\right) \geq A(H)+A\left(h_{j}\right)$ and $W_{j}^{2}\left(h_{j}\right) \geq A\left(h_{j}\right)$, where $h_{j}=(1 / 2 \mathrm{H}, \mathrm{H}), j=1,2$. After employee 1 threatens to quit in the second period, the problem for that employee becomes, $\operatorname{Max}\left\{0, f\left(1 / 2 H, \theta_{1}\right)-W_{1}^{2}(1 / 2 H)\right\}$, subject to $W_{1}^{2}(1 / 2 H) \geq A(1 / 2 H)$. $W_{j}^{2}(1 / 2 H)$

${ }^{11}$ For example, Hall and Lazear (1984) when both M and A are observed by one or both parties to the contract.

12 The 1999 Census Bureau County Business Patterns indicates that excluding government, railroads, and the self-employed, approximately 15 percent of all establishments have 20 or more employees, and 75 percent of all employees work in establishments with 20 or more employees.

${ }^{13}$ The response rate was $64 \%$ in the Educational Quality of the Workforce National Employers Survey, which was administered by the U.S. Bureau of the Census as a telephone survey in August and September 1994 to a nationally representative sample of private establishments with more than 20 employees (Lynch and Black, 1998). The response rate was 65.5 percent in Osterman's 1992 telephone survey of establishments with more than 50 employees (Osterman, January 1994). Holzer and Neumark (1999) report a response rate of $67 \%$ for establishments that were successfully screened in a telephone survey undertaken between June 1992 and May 1994. 


\begin{abstract}
${ }^{14}$ Note that the strategy is to not try to proxy the conceptual variables $\mathrm{f}(H, \theta)$ and $\mathrm{A}(H)$ separately, but rather proxy the gap between $\mathrm{f}(H, \theta)$ and $\mathrm{A}(H)$. Separate proxies for these conceptual variables would be difficult, since they will be determined by many of the same variables (e.g., education), or by unobserved variables (e.g., product price).

${ }^{15}$ Of course, the manager might be permitted to shift to a different job, e.g., a manager with a degree in engineering could become a part-time engineer. That too, however, may be costly to the establishment; there was a reason why the person was a manager and not an engineer.

${ }^{16}$ With regard to the first point, defined benefit pensions sometimes base a retired person's pension benefits on earnings during the final few years before retirement. In that case an older person who chooses to work half time at half pay prior to retirement could lose as much as half of all future pension benefits. Indeed, Michael Hurd calculates that in such a system, a 10 percent decrease in annual earnings can translate into a lifetime wealth loss of $150 \%$ of annual earnings (Hurd, 1996, p. 35). Such a pension will almost certainly discourage part-time work. This is not the case with defined contribution pensions. Since benefits are based on the amount of money in an individual account, a person who works half time in the final years before retirement receives lower benefits (because of lower contributions to that individual account), but the decrease is small and nothing close to a lifetime wealth loss of $150 \%$ of annual earnings.

With regard to the second point, under Internal Revenue Service regulations it can be quite difficult for active employees to receive pension benefits from their current employer's defined benefit pension plan. By implication, a worker who takes phased retirement (and thus stays with the current employer) may not be able to supplement earnings with payments from a defined benefit plan. This is less of an issue for a defined contribution plan. Internal Revenue Service regulations permit employers to set up defined contribution plans so that an active employee can draw pension benefits. The major federal limitation on this is that the employee must be over age 591/2. This is the essence of the regulations, which are arcane. A complete treatment would require several pages. Happily good discussions can be found in Fields and Hutchens (2002) and Penner, Perun and Steuerle (2002).

${ }^{17}$ Stanley D. Nollen, Brenda B. Eddy, and Virginia H. Martin (1977), and Mark Montgomery (1988).

${ }^{18}$ There is, of course, a statistical basis for separately estimating a model of the marginal and a model of the conditional. The parameter estimates that maximize the likelihood function for the marginal model and the parameter estimates that maximize the likelihood function for the conditional model are the parameter estimates that maximize the likelihood function for the unconditional probability that person i has an opportunity for phased retirement. To see this, arrange the data so that the first $\mathrm{m}$ observations have $\mathrm{Y}_{2 \mathrm{i}}=$ 1 , and the remaining $\mathrm{n}-\mathrm{m}$ observations have $\mathrm{Y}_{2 \mathrm{i}}=0$. Then the likelihood function takes the form,
\end{abstract}

$$
\prod_{i=1}^{n} P\left(Y_{1 i} \mid X_{1}, X_{2}\right)=\prod_{i=1}^{m} P\left(Y_{1 i} \mid X_{1}, X_{2}, Y_{2 i}=1\right) P\left(Y_{2 i}=1 \mid X_{1}, X_{2}\right) \prod_{i=m+1}^{n} P\left(Y_{2 i}=0 \mid X_{1}, X_{2}\right)=\prod_{i=1}^{m} P\left(Y_{1 i} \mid X_{1}, X_{2}, Y_{2 i}=1\right) \prod_{i=1}^{n} P\left(Y_{2 i} \mid X_{1}, X_{2}\right)
$$

Thus, one can maximize the likelihood function by separately maximizing $\prod_{i=1}^{m} P\left(Y_{1 i} \mid X_{1}, X_{2}, Y_{2 i}=1\right)$ and $\prod_{i=1}^{n} P\left(Y_{2 i} \mid X_{1}, X_{2}\right)$. By implication, there is no selection bias resulting from estimating the conditional in the sample with $\mathrm{Y}_{2 \mathrm{i}}=1$.

${ }^{19}$ More surprising is the result on whether older workers tend to be more productive than younger workers (variable 25). The result indicates that when an establishment permits phased retirement, it tends to also say that in the selected worker's job, older workers are more productive than younger workers. Perhaps the productivity of older workers in the selected worker's job is positively correlated with the productivity of older workers in other jobs in the establishment, and phased retirement is thereby more likely in the establishment.

${ }^{20}$ One reason why salary might be lower is that managers - who usually have higher salaries - tend to be in the set of workers with poor opportunities for phased retirement.

${ }^{21}$ The sample universe - the Dun and Bradstreet Strategic Market Record -- contains complete data on a vector of variables for all establishments in the initial sample, i.e., those that responded to all questions, those that responded to some questions, and those that did not respond at all. As such, one can not only 
address item nonresponse but also unit nonresponse. Given the information on establishments that did not respond, it was possible to compute sample weights from a model of the probability of response. When this was done the results in Tables 2 were virtually unaffected. Thus, this paper focuses on multiple imputations for item nonresponse.

${ }^{22}$ To implement multiple imputation for this paper, we first estimated a parametric imputation model; this was a multivariate normal model with 150 variables, 126 of which had at least some missing data. Survey variables were included if they were either used in Tables $3 \mathrm{a}$ or $3 \mathrm{~b}$ or were correlated with one or more of the Table 4 variables with the absolute value of the correlation coefficient being .35 or above. Some examples of the latter: a variable indicating that the establishment was part of a sole proprietorship, partnership or corporation; a variable indicating that the establishment was rented or owned by the operator; a variable indicating that an employee would be permitted to shift to part-time to care for a young child; and a variable indicating that the selected worker's job requires frequent travel. After performing several diagnostic checks and transforming variables when appropriate (see Allison (2002), pp. 39-40 for a discussion of these issues), a SAS procedure called Proc MI was use to estimate the imputation model, to randomly draw parameter values from the posterior distribution of estimated means and covariances, and to impute all variables simultaneously. Tables $3 \mathrm{a}$ and $3 \mathrm{~b}$ are based on ten data sets with imputations for the missing values.

${ }^{23}$ An alternative specification replaces the employer's rating of job performance with the full-time worker's annual salary. The estimated coefficient on salary is effectively zero (when salary replaces measures of job performance in models 2,4 , and 5 , the coefficient on salary in thousands of dollars is $.0002,-.0003$, and +.00008 respectively, with all t-statistics below one). While salary is positively and significantly correlated with the employer's rating of the selected worker's job performance, some high salary workers are in jobs that are not easily converted to part-time, e.g., managers. Moreover, in the section II model, the current wage is not a determinant of phased retirement, nor does it reveal current performance. Rather, it is a function of the alternative wage over the full duration of the implicit contract.

${ }^{24}$ It could conceivably be argued that these performance measures simply constitute multiple measures of an underlying latent construct. Factor analysis provides one way to address this, with the factor score associated with the largest eigenvalue used as an index of that underlying latent construct. This was done with the six variables in Model 3 of Table 3a that are included under the heading "Job Performance of SW." The largest eigenvalue was 2.492 and the second largest was .157. When the six performance measures in Model 3 of Table 3a are replaced by the resulting factor score, the coefficient on this factor score is positive with a t-statistic of 4.22. In Model 5 the coefficient is positive with a t-statistic of 3.67. ${ }^{25}$ In Table 3a model 4, a likelihood ratio test rejects at a .01 level the null hypothesis of a zero vector of coefficients on (a) demographic and performance characteristics, and (b) job characteristics. In Table 3a model 5, a likelihood ratio test rejects at a .01 level the null hypothesis of a zero vector of coefficients on (a) demographic and performance characteristics (b) job characteristics (c) establishment characteristics and (d) job characteristics and establishment characteristics. Since Table 3a uses multiple imputation, these tests are based on the average of the log-likelihood over the 10 models. Since Table $3 \mathrm{~b}$ model 4 is based on the same model as Table $3 \mathrm{a}$ model 4 , and since Table $3 \mathrm{~b}$ model 5 is based on the same model as Table $3 \mathrm{~b}$ model 5 ( the tables present different sets of coefficients), these likelihood ratio tests apply to Table $3 \mathrm{~b}$ as well.

${ }^{26}$ In his discussion of ordered probit, Greene (2000) indicates that the sign on an estimated parameter in a five category ordered probit determines the sign of the change in the probability for category 1 and 5 , while the change for categories 2, 3, and 4 are ambiguous. Following Greene, to investigate these other categories, marginal effects were computed using the parameters in the fourth model in Tables $3 \mathrm{a}$ and $3 \mathrm{~b}$. In all cases the marginal effect for category 4 has the same sign and a smaller absolute value than that in category 5. Similarly, marginal effects for categories 2 and 3 have the same sign and are smaller in absolute value than for category 1 . Thus, for these data the sign on the estimated parameters was predictive of the sign on changes in all five probabilities.

${ }^{27}$ A likelihood ratio test rejects at a .05 level the null hypothesis of a zero vector of coefficients on all of the Model 5 individual and establishment level pension and union variables $(\mathrm{P}$-value $=.030)$.

${ }^{28}$ The question is derived from Osterman (1992), question E25.

${ }^{29}$ The question is derived from Brady et. al. (1991), Direct Supervisor Survey, Question 1. 


\section{Bibliography}

AARP. "Easing the Transition: Phased and Partial Retirement Programs -- Highlights 1999." AARP, Washington, DC, 2000.

Allison, Paul David. Missing Data. Thousand Oaks, Calif. Sage Publications, 2002.

Brady, E. Michael, Richard H. Fortinsky, Kari Koss, Margaret Vishneau, and Colombo Mary. Employers' Views on the Value of Older Workers: Final Report, Human Services Development Institute, Edmund Muskie Institute of Public Affairs, University of Southern Maine, 96 Falmouth Street Portland, Maine, 1991.

Chen, Jennjou. "The Part-Time Labor Market for Older Workers." Mimeo, Cornell University, 2003.

Committee for Economic Development. New Opportunities for Older Workers. New York, New York: Committee for Economic Development, 1999.

Fields, Vivian, and Robert Hutchens. "Regulatory Obstacles to Phased Retirement in the ForProfit Sector." Benefits Quarterly 18, no. 3 (2002): 35-41.

Greene, William H. Econometric Analysis. Upper Saddle River, New Jersey: Prentice Hall, 2000.

Gustman, Alan L., and Thomas L. Steinmeier. "Minimum Hours Constraints and Retirement Behavior." Contemporary Policy Issues, a Supplement to Economic Inquiry 3 (1983): 7791.

_ "Partial Retirement and the Analysis of Retirement Behavior." Industrial and Labor Relations Review 37, no. 3 (1984): 403-15.

_. "Partial Retirement and Wage Profiles of Older Workers." Industrial Relations 24, no. 2 (1985): 257-65.

Hall, Robert, and Edward Lazear. "The Excess Sensitivity of Layoffs and Quits to Demand." Journal of Labor Economics 2, no. 2 (1984): 233-57.

Holzer, Harry J., and David Neumark. "Are Affirmative Action Hires Less Qualified? Evidence From Employer-Employee Data on New Hires." Journal of Labor Economics 17, no. 3 (1999): 534-69.

Hurd, Michael D. "The Effect of Labor Market Rigidities on the Labor Force Behavior of Older Workers." in Advances in the Economics of Aging, ed. David A. Wise, 11-58. Chicago and London: The University of Chicago Press, 1996.

Hutchens, Robert M. The Cornell Study of Employer Phased Retirement Policies: A Report on Key Findings. Ithaca, New York: School of Industrial and Labor Relations, Cornell University, 2003.

Hutchens, Robert M., and Karen Grace-Martin. "Employer Willingness To Permit Phased 
Retirement: Why Are Some More Willing Than Others?" Industrial and Labor Relations Review (2006, forthcoming).

Lynch, Lisa M., and Sandra E Black. "Beyond the Incidence of Employer-Provided Training." Industrial and Labor Relations Review 52, no. 1 (1998): 64-81.

Montgomery, Mark. "On the Determinants of Employer Demand for Part-Time Workers." Review of Economics and Statistics 70, no. 1 (1988): 112-16.

Nollen, Stanley D., Brenda B. Eddy, and Virginia H. Martin. "Permanent Part Time Employment: The Manager's Perspective." Employment and Training Administration, Office of Research and Development PB-268-390. Washington, D.C. School of Business Administration, Georgetown University, 1977.

Osterman, Paul. "How Common Is Workplace Transformation and Who Adopts It?" Industrial and Labor Relations Review 47, no. 2 (1994): 173-88.

—_. "M.I.T. Study of Work Organizations." M.I.T., Boston, Mass. 1992.

Penner, Rudolph G., Pamela Perun, and Eugene Steuerle. Legal and Institutional Impediments to Partial Retirement and Part-Time Work by Older Workers. Washington, D.C. Urban Institute, 2002.

Quinn, Joseph F., Richard V. Burkhauser, and Daniel A. Myers. Passing the Torch: The Influence of Economic Incentives on Work and Retirement. Kalamazoo, MI: W. E. Upjohn Institute for Employment Research, 1990.

Rebick, Marcus E. "Rewards in the Afterlife: Late Career Job Placements as Incentives in the Japanese Firm.” Journal of the Japanese and International Economies. 1995 Mar; 9(1):128.

Reimers, Cordelia, and Marjorie Honig. "The Retirement Process in the United States: Mobility Among Full-Time Work, Partial Retirement, and Full Retirement." in Redefining the Process of Retirement, ed. W. Schmahl, 116-31. Berlin Heidelberg: Springer-Verlag, 1989.

Ruhm, Christopher J. "Bridge Jobs and Partial Retirement." Journal of Labor Economics 8, no. 4 (1990): 482-501.

United States General Accounting Office. "Older Workers: Demographic Trends Pose Challenges for Employers and Workers ." Report to the Ranking Minority Member, Subcommittee on Employer-Employee Relations, Committee on Education and the Workforce, House of Representatives, GAO-02-85 . Washington, D.C., 2001.

William M. Mercer, Inc. "Phased Retirement and the Changing Face of Retirement." William M. Mercer, 2001. 